\title{
CSR and Related Terms in SME Owner-Managers' Mental Models in Six European Countries: National Context Matters
}

\author{
Yves Fassin • Andrea Werner • Annick Van Rossem • \\ Silvana Signori $\cdot$ Elisabet Garriga $\cdot$ Heidi von Weltzien \\ Hoivik · Hans-Jörg Schlierer
}

Received: 21 January 2013/Accepted: 4 February 2014/Published online: 11 March 2014

(c) The Author(s) 2014. This article is published with open access at Springerlink.com

\begin{abstract}
As a contribution to the emerging field of corporate social responsibility (CSR) cognition, this article reports on the findings of an exploratory study that compares SME owner-managers' mental models with regard to CSR and related concepts across six European countries (Belgium, Italy, Norway, France, UK, Spain). Utilising Repertory Grid Technique, we found that the SME ownermanagers' mental models show a few commonalities as well as a number of differences across the different country samples. We interpret those differences by linking individual cognition to macro-environmental variables, such as language, national traditions and dissemination mechanisms. The results of our exploratory study show that nationality matters but that classifications of countries as found in the comparative capitalism literature do not exactly mirror national differences in CSR cognition and that these classifications need further differentiation. The findings from our study raise questions on the universality of cognition of academic management concepts and warn that promotion of responsible business practice should not
\end{abstract}

Y. Fassin $(\bowtie)$

Vlerick Business School \& Ghent University, Reep 1,

9000 Ghent, Belgium

e-mail: y.fassin@skynet.be; yves.fassin@ugent.be

A. Werner

Middlesex University Business School, London, UK

e-mail: A.Werner@mdx.ac.uk

A. Van Rossem

KULeuven, Brussels, Belgium

e-mail: annick.van.rossem@skynet.be

S. Signori

Università degli Studi di Bergamo, Bergamo, Italy

e-mail: silvana.signori@unibg.it rely on the use of unmediated US American management terminology.

Keywords Business ethics - Cognition · Corporate social responsibility (CSR) · Cross-national study · Repertory Grid Technique $\cdot$ Small to medium sized enterprises

\section{Introduction}

After decades of renewed academic research into the importance of the idea that business organisations have social responsibilities, the concept and the usage of Corporate Social Responsibility (CSR) remain complex, multifaceted (Aguinis and Glavas 2012; Garriga and Melé 2004; Secchi 2007) and prone to national interpretations (Argandoña and von Weltzien Hoivik 2009). In their attempt to systematise CSR literature, Aguinis and Glavas (2012) divide the vast existing research into studies at institutional, organisational and individual level. Studies at

\author{
E. Garriga \\ EADA Business School, Barcelona, Spain \\ e-mail: egarriga@eada.edu \\ H. von Weltzien Hoivik \\ BI Norwegian Business School, Oslo, Norway \\ e-mail: heidi.hoivik@bi.no \\ H.-J. Schlierer \\ EM Lyon Business School, Lyon, France \\ e-mail: schlierer@em-lyon.com
}


the institutional level analyse which normative, culturalcognitive and regulative elements influence CSR, such as economic conditions (Campbell 2007), national, legal and cultural frameworks (e.g. Matten and Moon 2008), industry characteristics (e.g. Chiu and Sharfman 2011) and stakeholder influence (e.g. Sharma and Henriques 2005). Then there are studies focusing on the level where CSR takes place (organisational level). Examples of this kind of research include studies into firm motives (e.g. Bansal and Roth 2000), CSR activities and their relationship to financial performance (e.g. Orlitzky et al. 2003), and firm values as antecedents for CSR (Maignan et al. 1999). Finally, there are studies at individual level, which explore CSR from the point of view of individuals such as CEOs (e.g. Ormiston and Wong 2013) and employees (e.g. Gully et al. 2013; Rupp et al. 2013). In their review of the literature, Aguinis and Glavas (2012) point to a relative scarcity of individual (micro) level studies in CSR research, compared to institutional and organisational level studies (see also Lee 2008). It is important, however, to understand the individual level: even though 'CSR takes place at the organisational level of analysis', it is 'individual actors... who actually strategise, make decisions and execute CSR initiatives' (Aguinis and Glavas 2012, p. 953; see also Secchi 2009). Studies in this small, but growing research stream have used a range of approaches including psychological frameworks such as person-organisation fit (e.g. Gully et al. 2013), organisational justice (Rupp et al. 2013) and moral identity theory (e.g. Ormiston and Wong 2013). These frameworks are guided by the researchers' interest to uncover attributes, traits and perceptions of individuals that explain their attitudes and behaviours with regards to CSR. Among these psychological frameworks, there is one strand of research that uses a cognitive approach to CSR, which seeks to gain a direct understanding of how individuals think about and make sense of CSR. In other words, this research seeks to understand cognitive processes, structures and mental models relating to the CSR concept. This is the stream to which this article makes a contribution. Few studies target individual cognition in relation to CSR (Boal and Peery 1985; Crilly et al. 2008; Secchi 2009; Zollo et al. 2009). Further, while some of these studies draw from an international sample (Crilly et al. 2008; Zollo et al. 2009), the majority of these studies focus on one national context only (Boal and Peery 1985; Fassin et al. 2011), and at the time of writing, there is no research that compares managers' mental models regarding CSR across different countries. Our exploratory study fills this gap. By utilising Repertory Grid Technique (Fransella et al. 2004; Kelly 1955), we compare the mental models of SME owner-managers, as a specific group of individual actors, across six European countries; Belgium, Italy, Norway, France, the United Kingdom and Spain.
In doing so, we also respond to Aguinis and Glavas' (2012) call for more multilevel studies in the CSR field. That is research which analyses cross-level interactions and effects, and includes variables at more than one level of analysis (Aguilera et al. 2007; Hox 2002). Our study uses a qualitative, exploratory approach to multilevel analysis by using variables from our respondents' respective national contexts (macro-level) to explain and interpret differences in managers' mental models (micro-level) across six national samples.

The present study focuses on a fundamental and critical issue in CSR research, namely that a clear conceptualisation of CSR remains difficult and may, therefore, cause confusion among academics as well as practitioners (Fassin et al. 2011). This is particularly in view of the fact that CSR often overlaps with other concepts such as business ethics, sustainability, stakeholder management and corporate governance (Joyner and Payne 2002; Schwartz and Carroll 2008; Wheeler et al. 2003).

By investigating owner-managers of small to mediumsized enterprises (SMEs), our study contributes to research that explores CSR in SME contexts (Jamali et al. 2009; Jenkins 2004; Perrini 2006). SMEs, and their owner-managers, remain an under-researched entity in the CSR field (Lee 2008) even though about $99 \%$ of all business organisations in developed economies are SMEs, and they make a substantial contribution to national turnover and employment (Spence 1999). CSR research then in SMEs merits special attention due to the fundamental contribution that SME's make to national economies, and because these business organisations differ from large corporations not only in size but also in organisational set-up (Lee 2008; Spence 1999).

The remainder of this article is structured as follows. The next few sections shall set out the background and rationale for our study in more detail. These sections explain how our research relates to existing studies in both cognitive CSR and cross-national CSR research, and how our study makes a unique contribution to both domains. We then detail our chosen method Repertory Grid Technique, our research design and the sample selected for our investigation. Following on from this, we present, interpret and discuss our findings. The final sections of this article reflect on the limitations of our study and put forward concluding remarks.

\section{Literature Review}

\section{CSR and Cognition}

Cognitive research in CSR seeks to understand cognitive processes, structures and mental models related to the CSR concept (Basu and Palazzo 2008). These studies make a 
contribution to understanding the 'micro-foundations' of CSR (Morgeson et al. 2013).

There is a small stream of cognitive research in CSR. Cognition, however, is an important factor where wider debates about the application of a complex concept, like CSR, emerge (Gallie 1956). This is emphasised by Basu and Palazzo (2008, p. 123) who argue that it is important to understand 'the mental frames and sensemaking processes within which CSR is embedded' and they propose a process model based on the cognitive, linguistic and conative dimensions of sensemaking. At the same time, however, Basu and Palazzo (2008) develop their model from an organisational perspective, without making a clear distinction between managers as individuals or as representatives of their organisational context (Aguinis and Glavas 2012, p. 941).

The small number of studies that explicitly pay attention to individual managerial cognition in relation to CSR or socially responsible behaviour have employed a large variety of methodologies and focused on a range of different aspects. An early empirical study by Boal and Peery (1985) used a sample of undergraduate management students to carry out a multidimensional scaling analysis to determine three 'dimensions' of how individuals conceptualise the CSR construct (economic/non-economic outcomes, ethical considerations, consequences for relevant interest groups) by asking their respondents to compare and rate 'forced-choice' pairs of CSR outcomes.

Other studies have focused on the cognitive antecedents of individuals' socially responsible behaviour, which may affect their decision-making in organisational settings. Secchi (2009), for example, sets out in a conceptual article the various ways in which an individual's social environment (external resources) may shape cognitive processes that affect their socially responsible behaviour. He draws on the idea that individual cognition is distributed, that is, cognition is not confined to the human brain alone, but it is bound up with the individual's physical and social environment (Love 2004; Sutton 2004). Even though we do not test Secchi's (2009) model exactly, our study also broadly follows a distributed cognition approach and provides an empirical contribution to this area of research.

Crilly et al. (2008) used a different approach. They empirically investigated the importance of a set of psychological antecedents (values, affect and cognition) to corporate managers' socially responsible behaviour in a scenario-based study. Drawing from CSR and management literature, they tested the importance of four 'pre-determined' cognitive antecedents (moral, economic, reputation-based and legal reasoning). Similarly, Rose (2007) explored in a scenario-based study to what extent corporate directors employ legal or ethical reasoning in situations that call for a socially responsible decision.
Another set of studies have used scales measuring more directly individuals' beliefs about, and attitudes to, socially responsible behaviour of business organisations. Some scholars have used so-called PRESOR scales-Perceived Role of Ethics and Social Responsibility (Singhapakdi et al. 1996), for example, to investigate the link between corporate managers' beliefs and attitudes regarding CSR and corporate governance, and CSR practices (Godos-Díez et al. 2011), or the link between moral attentiveness, business ethics education and beliefs about ethics and social responsibility in business (Wurthmann 2013).

Also focusing on the social responsibility of businesses, or CSR, the RESPONSE project, a large interview-based study (Pedersen 2010; Zollo et al. 2009) investigated cognitive maps of corporate managers with regard to the ranking of corporate stakeholders, CSR issues and scope of CSR, and to what extent these managerial cognitive maps are aligned to those of their companies' stakeholders (Zollo et al. 2009).

A focus on cognitive maps of managers with regard to CSR can also be found in Fassin et al.'s studies (2009, 2011). The authors explore managers' mental models with regard to CSR in relation to other concepts prevalent in the business and society field. Their research addresses the problem and fundamental issue that there is a lack of clear understanding of the CSR concept in academia as well as in popular management literature, which, in turn may cause confusion among business practitioners as those who are called to engage in socially responsible action (Fassin et al. 2011). Several academic articles have tried to make sense of the complexities and facets of the CSR concept (e.g. Garriga and Melé 2004; Secchi 2007), but a clear conceptualisation of CSR remains difficult, also because it overlaps with other concepts such as business ethics, sustainability, stakeholder management and corporate governance (e.g. Joyner and Payne 2002; Schwartz and Carroll 2008; Wheeler et al. 2003). Fassin et al. $(2009,2011)$ chose to explore managers' mental models regarding CSR and related concepts by utilising Repertory Grid Technique (RGT), which is based on Kelly's Personal Construct theory (Kelly 1955), as a novel approach to studying CSR cognition. RGT is a creative and flexible set of methods (Fransella and Neimeyer 2003) that seeks to elicit people's implicit mental models they hold with regards to a specific topic (Fransella et al. 2004, p. 3), in our case, CSR concepts. RGT formalises people's outlook on the world and allows data that can be both qualitatively and quantitatively analysed (Fransella et al. 2004). RGT reduces researcher bias (Easterby-Smith 1980; Ginsberg 1989) and avoids 'forcing' an overly tightly constructed research design consisting of closed questionnaires and scales and 'artificial' scenarios affecting the thinking of the respondents as done in the some of the studies listed above. 
Fassin and Van Rossem (2009) studied the mental models of CEOs and opinion leaders and SME ownermanagers (Fassin et al. 2011). However, they restricted their study to one country (Belgium). Our study extends this research by comparing mental models of managers regarding CSR and related concepts across six different countries. Even though some of above mentioned studies draw from an international sample of managers (e.g. Crilly et al. 2008; Zollo et al. 2009), none of these studies has investigated differences in individual CSR cognition according to national context.

We follow Fassin et al.'s (2011) choice of sample and study owner-managers of SMEs as a specific group of managers. Investigating the cognition of SME ownermanagers in relation to CSR is interesting for the following reasons. First, because they usually are a major or sole owner and decision-maker in their organisation, and due to the relatively small size of their business, SME ownermanagers have the opportunity to directly shape organisational practices according to their personal values, in contrast to managers who are merely the 'agents' of absent shareholders (Spence 1999). SME owner-mangers are able to enact values other than profit (Curran and Blackburn 2001; Spence 1999; Spence and Rutherfoord 2001), which, in turn, may affect their perception of, and beliefs regarding, CSR. At the same time, because SMEs are more constrained in their resources than large organisations (Carland et al. 1984), they particularly depend for their survival on exchanges with their economic, social, cultural, geographical and political environments (Curran and Blackburn 2001, pp. 6, 7). The 'embeddedness' of SMEs in their wider environments may make a distinct impact on SME owner-managers' cognition regarding CSR compared to managers in large organisations. Finally, even though SME owner-managers cannot be equated with 'entrepreneurs', there is an overlap between the two entities (Stewart et al. 1999). Entrepreneurial cognition is said to differ from non-entrepreneurs. For example, Mitchell et al. (1997) argue that entrepreneurs use 'simplifying strategies' and perceptual processes and entrepreneurial expertise, thereby positing that entrepreneurs develop unique mental models and process information in a different way to nonentrepreneurs.

\section{Multilevel Analysis}

By comparing SME owner-managers' mental models with regard to CSR related concepts across a range of countries, we not only make a distinctive contribution to individual level studies on cognition, we also answer Aguinis and Glavas' (2012, p. 954) call for more CSR multilevel research. Multilevel analysis is based on the idea of nested arrangements; for example, individual members are nested in work groups or teams, which in turn are nested in organisational departments, which in turn are nested in organisations, and so on, until the national level (Hox 2002, p.10). Multilevel research, for instance, analyses how higher levels affect lower levels (downward cross-level effects), such as the influence of firm characteristics on employees' reactions to their firm's CSR initiatives (Aguinis and Glavas 2012; Hox 2002). Or researchers investigate how lower-level variables affect higher level variables (upward cross-level effect) such as the influence of CEO values on their firm's strategic priorities (Aguinis and Glavas 2012). Traditionally, multilevel research (e.g. Yidong and Xinxin 2013) is done through hypothesis testing and quantitative analysis, considering non-independence between levels both conceptually and analytically and taking into account cross-level effects (Snijders and Bosker 1999 cited in Aguinis and Glavas 2012, p. 957). In addition, Aguinis and Glavas (2012, p. 959) suggest that qualitative studies could enrich multilevel inquiry in the CSR field. In line with their recommendation, our exploratory study follows a qualitative approach as we investigate how variables related to national context (macro-level) affect individual cognition of the CSR concept (microlevel).

Lee (2008, p. 69) argues that it is important to conduct cross-national comparative CSR research as 'each country has a distinct social structure, dominant issues, institutions and interests, shaped by its unique history and cultural tradition'. He states that 'even in the face of rapid globalisation of economy, different societies maintain distinctive economic systems that structure business-society relations' (Lee 2008, p. 96) and, subsequently, CSR practice.

Cross-national comparative CSR research so far have included comparative studies of governmental approaches and policies with regard to CSR (Albareda et al. 2007, 2008; Freeman and Hasnaoui 2011) and analysis of how institutional features of national economic systems may influence approaches to CSR (Matten and Moon 2008; Midttun et al. 2006). The latter studies draw on different models of the 'varieties of capitalism' literature (Jackson and Deeg 2006), whose aim it is to draw out different types of capitalist economic systems according to features such as welfare systems, degree of government intervention and market regulation, and types of inter-firm relations. Amable (2003), for example, distinguishes five types of capitalism: Market-based, Mediterranean, Social-democratic, Continental European and Asian capitalism. Midttun et al. (2006) explore a similar classification for European economies in relation to their approaches to CSR (based on Sapir 2006): Nordic, Anglo-Saxon, Continental and Mediterranean models. All of these four clusters are represented in our study (see "Method" section). 
We shall explore the micro-macro link by first mapping out the similarities and differences in CSR cognition across six European countries and then by investigating why differences exist. For explanation of differences, we shall explore a range of features of the sample's national contexts, including historical developments and national-cultural traditions (Argandoña and von Weltzien Hoivik 2009), aspects of how these countries organise economic activity, as well as language. We regard this comparative investigation as particularly fruitful because of the notion of SME 'embeddedness' in their socio-cultural environments (as explained above). The merit of such investigation is also supported by studies that found that entrepreneurs show differences in cognition across national cultures (Mitchell et al. 2002) and different national business systems (Lim et al. 2010).

By linking the micro-level with the macro-level, we follow Secchi's (2009) distributed cognition approach, that is, we hold cognition is not a solipsistic activity but is influenced by an individuals' environment. We explore how an SME owner-managers' national context as an environmental variable might influence their individual cognition regarding CSR. In line with the distributed cognition view, we also regard language as distributed (Cowley 2009; Spurrett 2004; Thibault 2011). This distributed perspective challenges the classical view of language as an encoding/decoding mechanism based on inputs and outputs from an abstract language system and founded on computational models of cognition (Thibault 2011). Language, in this view, is neither a fixed code with an inventory of determinately identifiable linguistic units, nor a system of invariant form-meaning correlations, but rather a dynamic process that enables language to connect cognition, body and the social world (Spurrett 2004). Language is neither 'autonomous' nor separated from people. The distributed view focuses on human coordination, stressing how language functions between people (Cowley 2009) and reflects cultural perceptions of the world (Cowley 2007). Hence, linking the micro and the macro level; this focus on interactive sense-making and meaning construction leads to a better understanding of the individual and collective 'use' of CSR related concepts in different social and cultural environments.

\section{Method}

\section{Repertory Grid Technique}

Our study utilises RGT, to analyse SME owner-managers' mental models regarding CSR and related concepts. RGT has found many applications within different disciplines; especially in psychology (Fransella et al. 2004), management (Daniels et al. 1994; Reger and Palmer 1996) and information and communication technology research (e.g. Cho and Wright 2010; Edwards et al. 2009). RGT, however, has not been used extensively in the business and society field.

As mental models exist within the mind and are, therefore, not available for direct examination or measurement (Eden 1992; Jones et al. 2011), a variety of elicitation techniques and related mapping methods have been used in order to disclose and represent mental models (Eden 1992). RGT is a structured interview technique that elicits the mental models of individuals (Fransella et al. 2004). It is an engaging conversational tool for investigating the way people construe and make sense of their world (Stewart and Stewart 1981; Wright 2006). RGT is considered appropriate for analysing the composition of mental models, as well as for comparing actors' mental models (Fiol and Huff 1992; Fassin and Van Rossem 2009).

RGT is underpinned by Kelly's (1955) Personal Construct Theory, a cognitive theory, which posits that bipolar constructs (such as nice vs. awful) are the primary mechanism that individuals use to organise, simplify and interpret the mass of stimuli which confront them. RGT aims at eliciting such bipolar personal constructs that interviewees personally use in order to deal with a certain issue and aims at uncovering how these bipolar constructs relate to the topic researched.

RGT places the focus on the way people see the world through their own 'theories in use', thus making implicit and tacit knowledge, that underlies practices, explicit (Wright 2006). In its purest form (as conceived by Kelly 1955), RGT is an ideographic technique, that is, it seeks to elicit both 'elements', that is 'things and events' (Fransella et al. 2004, p. 15) and 'constructs', which the respondents use to describe said things and events.

At the end of the RGT exercise, the respondent will have constructed a two-dimensional grid, containing elements and constructs, as well as ratings of constructs in relation to the elements. The grids yield a rich set of interpretative data and permits a mixed method approach for data analysis (Bood 1998), for example, content analysis, weighted multidimensional scaling (WMDS) and Euclidean distances (ED) within the thee-dimensional cognitive maps, which are used in our research and which are explained in detail in the data analysis section. The grids formalise how people view the world, and they enable us to note what is surprising and individual about the structure and content of people's outlook on the world (Fransella et al. 2004, p. 5). As such, the information RGT provides is not to be regarded as a product of a 'scientific method' but a formalised version of the 'kind of understanding we are always in the process of gaining about each other' (ibid.). 
The validity and reliability of the RGT method is grounded in its 'usefulness', and whether it is something that gives insight and 'understanding' into a problem (Fransella et al. 2004 , p. 152 , in reference to Kelly). As such it has a different approach compared to quantitative methods that use hypothesis testing and significance checks to establish validity and reliability.

In our study, we used a partial RGT design, where elements are provided (in our case, CSR concepts), and personal bipolar constructs are elicited. Partial grid design is a slight departure from Kelly's personal construct theory, but it has been acknowledged that a pure ideographic approach yields data that are difficult to compare (Hodgkinson and Wright 2002). When the researcher wants to compare responses of (groups of) respondents, partial grid design is recommended (Reger 1990). Partial grid design does not constrain the resulting cognitive maps to preconceived ideas of what constitutes CSR and CSR-related concepts, as personal constructs are still elicited. However, in order to further improve comparability between responses, we also supplied a number of constructs, in addition to the elicited ones. This is an approach that has been used by a number of RGT researchers (Fransella et al. 2004 , p. 46). RGT approaches that work with completely standardised stimuli and attributes employed in the elicitation process are often referred to as being a nomothetic approach (Hodgkinson 2002). Thus we combined the advantages of an ideographic and a nomothetic approach in our study (Daniels and Johnson 2002; Daniels et al. 2002; Hodgkinson 2002). Both our selection procedure for elements (CSR concepts) and supplied constructs are detailed below.

\section{Design of the Study}

\section{Selection of Concepts}

As mentioned above, we used a partial grid design for our study where a set of elements or concepts representing the research topic is provided (Easterby-Smith 1980; Edwards et al. 2009). The CSR concepts selected as elements for the study were chosen on the basis of prominence in academic 'business and society' literature through citation analysis based on the ABI-Inform Proquest database. We started from an initial list of 20 elements including the six major concepts from Egels' (2005) analysis, some additional subdomains and some differing concepts such as shareholder value. Thirteen elements were selected and further reduced to 9 after tested and checked by independent experts (see Fassin et al. 2011 for further details). The retained nine elements included five central concepts: CSR, business ethics, sustainability, stakeholder management and corporate governance. These concepts also correspond to the
CSR concepts that Carroll (1999) identifies as important in his review of the historical development of the CSR field. The literature (see Fassin et al. 2011) points out links and overlapping meanings between these concepts, which makes them particularly interesting for our investigation. For example, many scholars regard CSR and business ethics as interchangeable terms (Epstein 1987; Joyner and Payne 2002; Vogel 1991) or at least overlapping concepts (Garriga and Melé 2004; Matten and Moon 2008; Trevino and Weaver 2003). De George (1987) states that CSR is part of business ethics, whereas others regard business ethics as a component of CSR (see Schwartz and Carroll 2008). Some researchers see an overlap between CSR and sustainability (Cramer et al. 2006; Wheeler et al. 2003). Pater and van Lierop (2006) consider stakeholder management as a way to implement CSR, and Garriga and Melé (2004) regard stakeholder management as an aspect of CSR, whereas Wheeler et al. (2003) consider CSR, sustainability and stakeholder management to be interwoven concepts. The link between CSR and corporate governance is emphasised, in discussions that regard CSR as constituting an important part of corporate governance (Aguilera et al. 2006; Luo 2006) or as an extended model of corporate governance (Money and Schepers 2007; Sacconi 2006). For better differentiation, we included four further concepts: shareholder value, safety, code of ethics and philanthropy. Shareholder value was included to test one of the most debated issues in CSR studies: the link between CSR and financial performance. Indeed, a lot of attention (perhaps too much, see Wood 2010) has been given to this link (see for example Margolis and Walsh 2003), but there is still no clear business case for CSR (Barnett and Salomon 2012). Code of ethics was included as it is often through such codes that companies commit themselves to social and ethical responsibilities (Bondy et al. 2008). We also included safety as this concept encompasses product and workplace issues, which have been linked to CSR (Boal and Peery 1985; see also Secchi 2007, p. 356). Finally, we included philanthropy as in classical Anglo-Saxon CSR literature, philanthropy is considered to be one of the pillars of CSR (Carroll 1991; Porter and Kramer 2006b).

\section{Selection of Constructs}

As mentioned above, we also opted to select a number of bi-polar constructs (used to rate the concepts), in order to enable comparison between the different country samples (Fransella et al. 2004; Gully et al. 2013; Hodgkinson 1997, 2002; Reger 1990; Stewart and Stewart 1981). These constructs were presented to the respondents after the elicitation exercise, if they had not already mentioned those constructs in the first phase of the RGT interview. 
The supplied constructs were selected from relevant themes in the business and society literature and were tested in two pilot interviews. ${ }^{1}$ In their study, Boal and Peery (1985) established CSR as a multi-dimensional concept with the following dimensions: economic vs. noneconomic outcomes, ethical considerations, and the consequences for relevant specific groups. Like Boal and Peery (1985) our choice of constructs included the ethical dimension ('ethical content vs. no ethical content'). Furthermore, our choice of constructs was informed by important themes in the CSR literature. There has been a debate as to the extent that CSR is or should be voluntary or mandated by government (voluntary vs. compliance) (Matten and Moon 2008). Also, while some managers and companies engage in CSR out of sincere conviction (Lee 2008), others may use CSR in an opportunistic manner, as a window-dressing or public relation exercise (Robertson and Nicholson 1996). Some authors point out that CSR is a fashionable concept, while others regard it as a more classic one (Abrahamson 1996; Van Rossem and van Veen 2011). The literature also discusses the scope of CSR (encompassing vs. specific) (Pedersen 2010) and the strategic function of CSR versus its operational aspects (Porter and Kramer 2006a; Secchi 2007). It is also interesting to investigate to what extent practitioners and especially SME leaders might consider CSR concepts relevant for their own situation (Lepoutre and Heene 2006; Stewart et al. 1999).

\section{Sample}

The six countries selected for the study fit into Sapir's (2006) and Amable's (2003) classifications of economies: Norway (Nordic or Social-democratic), the UK (AngloSaxon or Market-based), Belgium and France (Continental European), and Italy and Spain (Mediterranean). A first study was conducted in the Dutch speaking part of Belgium (Fassin et al. 2011) in 2007. A replication of the Belgian study was undertaken in Italy in 2008, and in Norway, France, UK and Spain in 2009.

In each country, convenience sampling was used for access and to expeditiously follow up interviews. Potential interviewees were selected in different ways across countries but mainly through various business networks (local Chambers of Commerce, trade associations, business

\footnotetext{
1 The initial study in Belgium used the following supplied constructs: relevant for my company versus not relevant; practical concept versus theoretical concept; opportunism, marketing or public relations versus sincere conviction; ethical concept versus has nothing to do with ethics; decency of governance versus has nothing to do with decent governance; fashion or hype versus classic concept. The construct pair essential versus not essential was supplied in the Spanish and Italian study only.
}

referral networks), business school databases and personal contacts.

In order to enable comparison, our samples, and respondents within the samples, had to meet the following criteria:

Sample Size When using RGT, a sample of 15-25 interviewees within the population is deemed adequate size to generate sufficient bipolar constructs to approximate the different meanings of a given situation (Easterby-Smith 1980; Ginsberg 1989) and construct mental models.

Ownership/Management We targeted SME ownermanagers, that is, individuals who were both major shareholders/sole owners of their business and a key decision-maker in their organization.

Organisational Structure. Given the variety of SMEs, it was necessary to further limit the target group (Longenecker et al. 1996). Only businesses that covered at least three functional areas with different functional staff were targeted.

Nationality. The respondents' businesses had to be headquartered in the respective sample country.

\section{Sample Description}

In each country 20 respondents were interviewed (with the exception of Belgium, where 23 interviews were conducted). The total interviews added up to 123 SME ownermanagers spread across the six European countries. Table 1 provides some descriptive statistics of our samples with regards to age, education and gender of respondents, type of SME venture and number of employees.

The majority of SMEs interviewed ( $85 \%$ ) conformed to the European Commission's definition of SME, with a size of 10-49 employees for small firms and 50-250 for medium-sized firms (European Commission 2014), except for a few companies exceeding this requirement (in France and the UK), and a few companies employing less than 10 employees (in Belgium, Norway and the UK). It should be noted, however, that an exact definition of what constitutes a SME remains difficult, especially in view of sector differences (Curran and Blackburn 2001, pp. 8-14). Except for a few startup companies, most SMEs in the samples had been running for more than 5 years. Our samples contained a mix of manufacturing businesses, businesses providing services and businesses involved in distribution activities.

The RGT interviews were held in locations close to the universities in which the researchers are based, except for Belgium where the interviews were held in all five Flemish provinces. In the other countries, interviews were conducted in the province of Bergamo (Lombardia) in Italy, around Oslo in Norway, in the Lyon area in France, in Barcelona in Spain and in a $100 \mathrm{~km}$ radius around London in the UK. However, the location of the interviewees does 
Table 1 Sample Description

\begin{tabular}{llllllll}
\hline & Belgium & Italy & France & Norway & UK & Spain & Total \\
\hline Number of interviews & 23 & 20 & 20 & 20 & 20 & 20 & 123 \\
Number of employees (range) & $5-170$ & $15-250$ & $27-480$ & $3-80$ & $8-290$ & $35-200$ & $3-480$ \\
Number of employees (average) & 32 & 84 & 165 & 23 & 55 & 93 & 87 \\
Age of respondents & $35-60$ & $32-65$ & $31-60$ & $31-58$ & $31-63$ & $38-58$ & $31-65$ \\
Main age bracket & $40-45$ & $<45$ & $>50$ & $45-55$ & $40-55$ & $40-50$ & $40-55$ \\
Number of female respondents & 2 & 6 & 4 & 3 & 2 & 2 & 19 \\
Education of respondents: minimum & 11 & 11 & 15 & 17 & 8 & 11 & 73 \\
$\quad$ Master's degree & & & & & & & \\
Type of venture & 15 & 15 & 6 & 5 & 3 & 11 & 55 \\
$\quad$ Inherited & 5 & 5 & 6 & 15 & 10 & 9 & 50 \\
Founders & 3 & - & 8 & - & 7 & - & 18 \\
$\quad$ Acquired & & & & & & & \\
\hline
\end{tabular}

Table 2 Overview of the terminology used in the different languages

\begin{tabular}{|c|c|c|c|c|c|}
\hline English (UK) & Dutch & French & Italian & Norwegian & Spanish \\
\hline $\begin{array}{l}\text { Corporate Social } \\
\text { Responsibility } \\
\text { (CSR) }\end{array}$ & $\begin{array}{l}\text { Maatschappelijk } \\
\text { verantwoord } \\
\text { ondernemen }\end{array}$ & $\begin{array}{l}\text { RSE (responsabilite } \\
\text { sociale de l'entreprise }\end{array}$ & $\begin{array}{l}\text { Responsabilita sociale di } \\
\text { impresa (also the original term } \\
\text { CSR) }\end{array}$ & $\begin{array}{l}\text { Bedriftens } \\
\text { samfunnsansvar }\end{array}$ & $\begin{array}{l}\text { Responsabilidad } \\
\text { Social } \\
\text { Corporativa }\end{array}$ \\
\hline Business Ethics & Zakenethiek & Ethique des affaires & $\begin{array}{l}\text { Etica d'impresa Etica degli } \\
\text { affari }^{\text {a }}\end{array}$ & $\begin{array}{l}\text { Nærings livs e } \\
\text { tikk }\end{array}$ & $\begin{array}{l}\text { Etica } \\
\text { Empresarial }\end{array}$ \\
\hline $\begin{array}{l}\text { Corporate } \\
\text { Governance }\end{array}$ & Deugdelijk bestuur & $\begin{array}{l}\text { Gouvernement } \\
\text { d'entreprise } \\
\text { Gouvernance } \\
\text { d'entreprise }\end{array}$ & Corporate governance & $\begin{array}{l}\text { Eierstyring og } \\
\text { selskapsledelse }\end{array}$ & $\begin{array}{l}\text { Gobierno } \\
\text { Corporativo }\end{array}$ \\
\hline Code of ethics & Ethische code & Code d'ethique & Codice etico & $\begin{array}{l}\text { Etiske } \\
\quad \text { retningslinjer }\end{array}$ & Codigo de Etica \\
\hline Philanthropy & Liefdadigheid & Philantropie & Filantropia/beneficenza & Veldedighet & Filantropia \\
\hline Safety & Veiligheid & Sécurité & Sicurezza & Sikkerhet/HMS & Seguridad \\
\hline $\begin{array}{l}\text { Shareholder } \\
\text { Value }\end{array}$ & Aandeelhouderswaarde & $\begin{array}{l}\text { Valeur pour } \\
\text { l'actionnaire }\end{array}$ & Valore per gli azionisti & $\begin{array}{l}\text { Eiernes } \\
\text { avkastning }\end{array}$ & $\begin{array}{l}\text { Valor para el } \\
\text { accionista }\end{array}$ \\
\hline $\begin{array}{l}\text { Stakeholder } \\
\text { Management }\end{array}$ & $\begin{array}{l}\text { Stakeholder } \\
\text { Management }\end{array}$ & $\begin{array}{l}\text { Gestion des parties } \\
\text { prenantes }\end{array}$ & $\begin{array}{l}\text { Portatori di interessi (the } \\
\text { original term "stakeholder"' is } \\
\text { much more used) }\end{array}$ & $\begin{array}{l}\text { Fokus på } \\
\text { interessegrupper }\end{array}$ & $\begin{array}{l}\text { Grupos de } \\
\text { Interes }\end{array}$ \\
\hline Sustainability & Duurzaam ondernemen & $\begin{array}{l}\text { Développement } \\
\text { durable }\end{array}$ & Sostenibiltà & $\begin{array}{l}\text { Bærekraftig } \\
\text { utvikling }\end{array}$ & Sostenibilidad \\
\hline
\end{tabular}

a Second choice, both terms mentioned

b This term was only mentioned when first term was not clear to the respondent

not affect the results of our study (national level) because CSR dissemination efforts (laws, initiatives, campaigns) in all six countries have been at national or supranational (European level); and not at the regional level.

Even though we cannot claim that the samples are fully representative, because of our convenience sampling strategy, we arrive at informed generalisations from the findings of our exploratory study, because each sample met the same requirements regarding the sample size necessary to conduct RGT, role of the respondents in their company and their company's structure.

\section{Data Collection}

As the study was carried out in different language contexts, all elements were supplied, wherever possible, in the local language. Table 2 shows an overview of the terms used in the different languages. Since some concepts were not easy to translate, sometimes two different translations were used, as was the case for business ethics in Italian, and corporate governance in France. For some concepts, such as stakeholder management, the English term was provided alongside the local translation. 
The RGT interview was conducted as follows. The elements (CSR concepts) were written on individual cards. At the beginning of each interview the researcher checked whether the interviewee understood what these nine elements entailed (Fransella et al. 2004; Janckowicz 2003. In the first phase of the RGT interview (elicitation phase) the respondent was asked to take three cards at random. This is called a triad. Respondents were asked to identify any way in which any two of the CSR concepts are alike in some way, yet different from the third element (Kelly 1955; Neimeyer 2002). Respondents had to take all elements in the triad into consideration. This leads to better differentiation of bipolar constructs (Hagans et al. 2000). Triading was repeated until respondents did no longer mention any new constructs. There is no minimum or maximum number of triads (Edwards et al. 2009; Tan and Hunter 2002).

The elicited personal bipolar constructs were inventoried on grid sheets. After triading, respondents were asked to rate on these grid sheets on a 7-point Likert scale how the elicited bipolar constructs applied to each of the nine elements in a row-wise manner, as this approach enables interviewees to compare and evaluate the elements with each other and will lead to less use of midpoints (Metzler et al. 2002).

In the second phase of the RGT interview, we supplied a number of bipolar constructs, if respondents had not mentioned these constructs in the elicitation exercise, and asked the respondents to rate these supplied constructs across all CSR concepts as well.

During the RGT exercise, most interviewees spontaneously gave comments pointing out links and differences between the various concepts. These comments were recorded, analysed and classified in order to provide additional qualitative insights. They also informed our interpretation of our quantitative data (see below). During the interview, the interviewers took care not to offer cues, as this would have imposed the researcher's own cognitive structure on the interviewees (Reeve et al. 2002; Tolliver and Neimeyer 2002).

\section{Data Analysis}

The RGT card game for eliciting constructs and the rating process resulted in 19-23 (number of interviews) twodimensional grids or matrices ( 9 elements versus elicited and supplied bipolar constructs) per country, containing the ratings given by the respondents (Grice 2002). The individual grids for each country were then merged into one grid sheet. Data emerging in grids can be analysed through a variety of qualitative and quantitative techniques (Dunn and Ginsberg 1986). To investigate and represent relationships between elements, distances are particularly effective (Mackay 1992; Bell 2003; Fransella et al. 2004). We used content analysis to
Table 3 Total number of constructs and elicited constructs per country

\begin{tabular}{llc}
\hline Country & $\begin{array}{l}\text { Total number } \\
\text { of constructs }\end{array}$ & $\begin{array}{l}\text { Number of elicited } \\
\text { constructs }\end{array}$ \\
\hline Belgium & 313 & 226 \\
Italy & 164 & 57 \\
Norway & 202 & 133 \\
France & 212 & 120 \\
UK & 211 & 82 \\
Spain & 214 & 17 \\
\hline
\end{tabular}

Table 4 Elicited constructs per interviewee per country

\begin{tabular}{llcccc}
\hline Country & Minimum & Maximum & M & Mean & SD \\
\hline Belgium & 6 & 14 & 9.3 & 10 & 2.12 \\
Italy & 1 & 5 & 3.0 & 3 & 1.49 \\
Norway & 5 & 10 & 6.6 & 6 & 1.23 \\
France & 4 & 8 & 6.0 & 6 & 0.94 \\
UK & 3 & 6 & 4.1 & 4 & 1.02 \\
Spain & 5 & 7 & 5.9 & 5 & 0.49 \\
\hline
\end{tabular}

compare constructs between countries and WMDS and ED to analyse and represent distances between concepts.

\section{Content Analysis}

Content analysis was used to generate construct categories to enable comparison of constructs across countries. Theoretical support for such analysis is provided by Kelly's commonality corollary and sociality corollary (Reger 1990). The number of bipolar constructs produced per interviewee varied from 1 to $14(M=5.88 ; \mathrm{Me}=6)$. Table 3 shows the number of elicited constructs and total number of constructs per country, and Table 4 provides statistics about the number of elicited constructs per interviewee in each country.

The researchers created an inventory of all elicited bipolar constructs to enable the creation of construct categories. Two raters (one having conducted the Belgian study and one from each country) independently coded the elicited bipolar constructs across respondents into categories using the method set up by Janckowicz (2003). Every construct from each grid was coded (initials of name interviewee, number of order of appearance of the construct, country, elicited, supplied). The coded constructs were sorted to form categories of similar constructs. New categories were created, and combined or broken down when required. A 'Miscellaneous' category was created for unclassifiable items. No limit on the number of categories was imposed. This resulted per rater in a table showing 
categories which were mutually exclusive and exhaustive category descriptions, and individual constructs that fitted under each category. The resulting tables were compared and a measure of agreement as a percentage of all constructs was computed, ranging from $90.8 \%$ (France) to $89.8 \%$ (Italy), $88 \%$ (Spain), $87.6 \%$ (Norway), $79.3 \%$ (UK) and $78.9 \%$ (Belgium). Janckowicz (2003) states that at least $90 \%$ accordance should be reached. As this threshold was not met for all country samples, the researcher engaged in discussions to improve the measure of agreement. $100 \%$ accordance was finally reached, which met and exceeded Janckowicz' (2003) requirement for reliability. The agreed construct categories were used in subsequent analyses (see Table 6 further below).

\section{Weighted Multidimensional Scaling}

In order to draw mental maps, we used WMDS, a spatial technique, which is based on the assumption that a given group of actors share a common set of underlying dimensions in their mental models of a particular domain. The main feature of WMDS is that both individual and collective cognition can be taken into account (Ginsberg 1989; Hodgkinson 1997). WMDS captures the information contained in the input matrices in as few dimensions as possible and offers a common model. It also gives "weight" to responses that are shared among the respondents in one sample, similar to factor loadings in conventional principal component analysis (Hair et al. 1998).

For the WMDS analysis, Individual Differences SCALing (INDSCAL) (Caroll and Chang 1970) we employed the ALSCAL algorithm (Takane et al. 1977) in SPPS $15 .^{2}$ The input for the ALSCAL procedure were distances, square symmetric. For calculating these distances the raw ratings given by each respondent (which are similarity judgments) for each bi-polar construct across all provided CSR concepts during the RGT exercise, ED between the elements were calculated (Wijnen et al. 2002). ${ }^{3}$ For this, the Proximities or Distance module in SPPS was used. This resulted in a $9 \times 9$ matrix of ED

\footnotetext{
$\overline{2}$ The precise technical way in which the INDSCAL process is accomplished varies from one computer algorithm to another. IN SPPS both PROXSCAL and ALSCAL algorithms implement the INDSCAL model as weighted Euclidean model. ALSCAL stands for Alternating least squares program developed by Takane et al. (1977). We chose ALSCAL, as this algorithm is more widely known and used in management studies (Hodgkinson 1997, 2005).

${ }^{3}$ In Italy, 20 interviews were conducted. The data of all 20 interviews were used for the content analysis. For the WMDS procedure, only the data of 19 interviews was used due to one outlier in the rating exercise. For similar reasons in France, one of the 20 interviews was not included in the WMDS analysis. 4 We thank Denis Constales, Department of Mathematics at Ghent University for the drawing of this figure.
}

between the elements per respondent. These matrices were grouped per country and were the input for the WMDS procedure (ALSCAL) (Wijnen et al. 2002, p. 513).

For ALSCAL, the routine was set to compute solutions from four down to two dimensions. Various levels or transformations were computed: level = ordinal (untie), level $=$ ordinal (tied) and level interval. The level showing best results based on stress and RSQ (both indices showing how well a proposed WMDS solution fits the data) should be retained (Sturrock and Rocha 2000). We retained a threedimensional common space solution as there is improvement in fit (considering both RSQ and Stress) when the number of dimensions is increased from two to three (see Table 8 in Appendix section). There is even more improvement in fit when dimensions are increased from three to four, but because it is impossible to visualise a four-dimensional model, we kept a three-dimensional solution. The threedimensional common spaces or mental maps per country with respect to each management concept are plotted in Fig. 1. Table 5 shows the stimulus coordinates associated with the three-dimensional solution of each country.

\section{ED in Country Common Space}

In order to allow for a more detailed exploration of the three dimensional solutions, we calculated ED within the country common spaces. These stimulus coordinates of the three dimensional solutions (Table 5) where the input in the Proximities or Distance module of SPPS to calculate ED. These ED are reported in Table 7 and point out how far (or close) the points (elements) are from each other in the three dimensional solutions per country and are thus a proxy for differentiation between concepts. The link between the concepts is not necessarily linear, but the distance (not the line) illustrates the link or absence of link (small distance indicates very close link, large distance indicates absence of link). Because these ED are the result of the WMDS procedure, which weighted the ratings in the individual grids, they do not represent means of individual ED in the country samples. As a result, we have only six observations per ED across our six samples, and because of these low numbers it is not possible to run a meaningful statistical robustness check such as $t$ test or ANOVA on them, but we can report on trends and tendencies, which need further testing.

\section{Results}

The Content of Mental Models: Constructs

We first compared the elicited constructs that the respondents used when asked to describe the CSR concepts presented to them as building blocks of their mental models 
Fig. 1 Three-dimensional Group Space for six national groups of SMEs representing the nine elements. The red lines in the cubes delineate the distances between CSR, business ethics and corporate governance for better visualisation. (Color figure online)
A

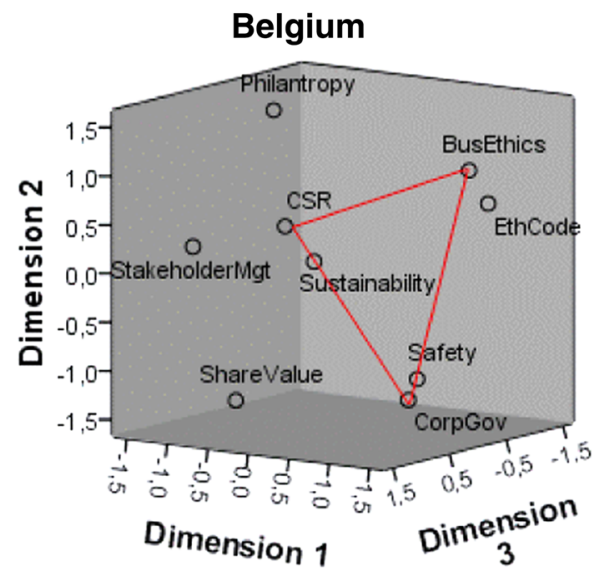

C

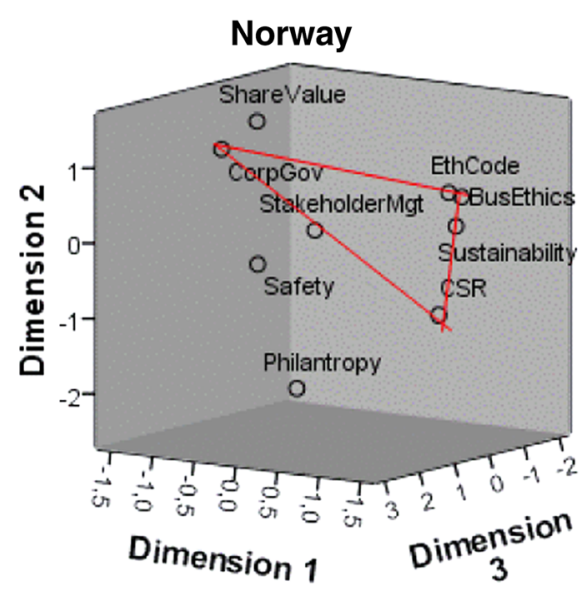

$\mathbf{E}$

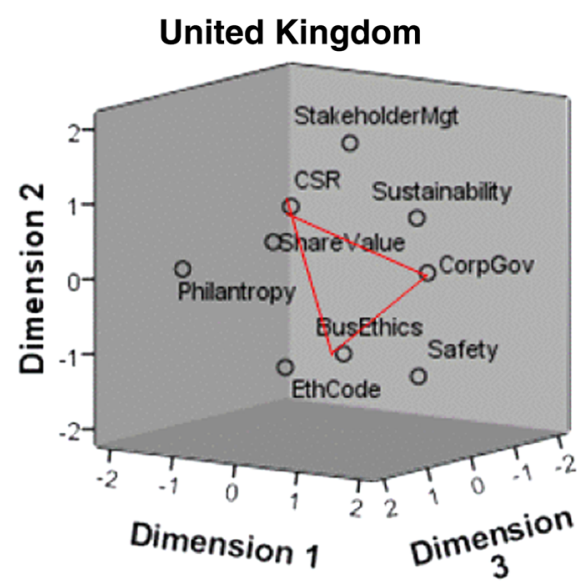

B

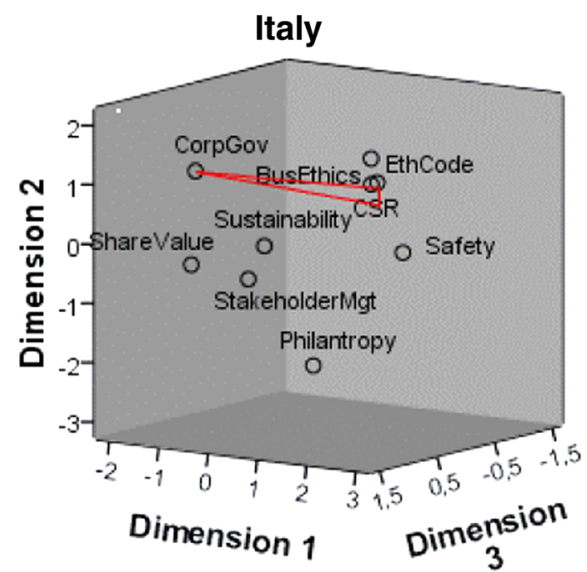

D

France

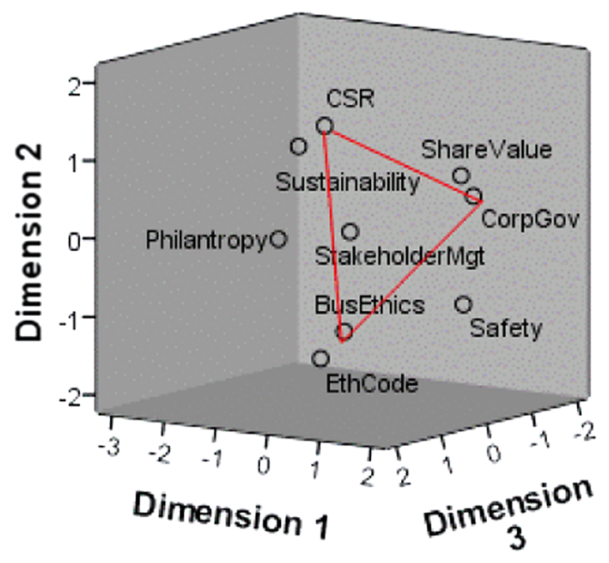

F

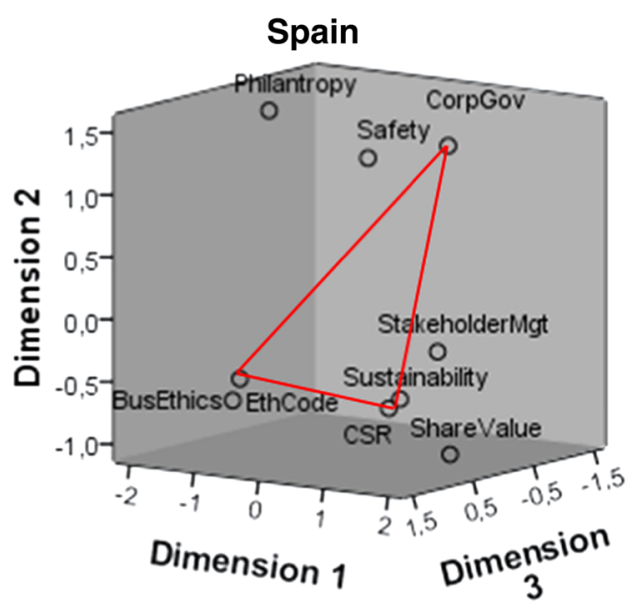

across the six countries. Based on the content analysis, a final table (Table 6) was drawn, listing all construct categories and the frequency of mention for each country sample. The frequency in which constructs occur in categories can point to the importance of these categories in the minds of participants (Janckowicz 2003).
We found a total of 30 construct categories in our sample. Half of the 30 construct categories were common in all six countries, which indicates that European SME owner-managers display considerable similarity in the choice of words to describe the concepts presented to them, although the country samples showed variation in the 
Table 5 Stimulus coordinates associated with the three-dimensional group space representing the nine elements for the full sample of interviewees for the six countries

\begin{tabular}{|c|c|c|c|}
\hline Element & $\begin{array}{l}\text { Dimension } \\
1\end{array}$ & $\begin{array}{l}\text { Dimension } \\
2\end{array}$ & $\begin{array}{l}\text { Dimension } \\
3\end{array}$ \\
\hline \multicolumn{4}{|c|}{$\begin{array}{l}\text { Belgium }(N=23 ; \text { Stress }=0.21 ; R S Q=0.43)(A L S C A L \\
\quad \text { Level }=\text { ordinal })\end{array}$} \\
\hline Corporate Governance & 1.22 & -1.16 & 0.59 \\
\hline Safety & -0.02 & -1.35 & -1.34 \\
\hline Business Ethics & 0.94 & 0.95 & -0.88 \\
\hline Code of Ethics & 1.01 & 0.59 & -1.12 \\
\hline $\begin{array}{l}\text { Stakeholder } \\
\text { Management }\end{array}$ & -1.29 & 0.19 & 0.81 \\
\hline Shareholder value & -1.26 & -1.49 & 0.09 \\
\hline Sustainability & 0.58 & 0.30 & 1.33 \\
\hline Philanthropy & -1.41 & 1.35 & -0.79 \\
\hline CSR & 0.22 & 0.63 & 1.33 \\
\hline \multicolumn{4}{|c|}{$\begin{array}{l}\text { Norway }(N=20 ; \text { Stress }=0.23 ; R S Q=0.51)(A L S C A L \\
\text { Level }=\text { ordinal untie })\end{array}$} \\
\hline Corporate Governance & -1.24 & 1.01 & 0.73 \\
\hline Safety & -0.15 & -0.19 & 2.28 \\
\hline Business Ethics & 1.02 & 0.51 & -0.76 \\
\hline Code of Ethics & 0.84 & 0.54 & -0.81 \\
\hline $\begin{array}{l}\text { Stakeholder } \\
\text { Management }\end{array}$ & -1.02 & -0.28 & -1.42 \\
\hline Shareholder value & -1.20 & 1.28 & -0.19 \\
\hline Sustainability & 1.31 & 0.26 & 0.09 \\
\hline Philanthropy & -0.61 & -2.16 & 0.08 \\
\hline CSR & 1.06 & -0.97 & 0.01 \\
\hline \multicolumn{4}{|c|}{$\begin{array}{l}U K(N=20 ; \text { stress }=0.20 ; R S Q=0.42)(A L S C A L \\
\text { Level }=\text { ordinal })\end{array}$} \\
\hline Corporate Governance & 1.64 & 0.18 & 0.16 \\
\hline Safety & 1.36 & -1.26 & -0.03 \\
\hline Business Ethics & -0.39 & -1.25 & -0.82 \\
\hline Code of Ethics & -0.58 & -1.29 & 0.25 \\
\hline $\begin{array}{l}\text { Stakeholder } \\
\text { Management }\end{array}$ & 0.15 & 1.71 & -0.20 \\
\hline Shareholder value & 0.38 & 0.72 & 1.90 \\
\hline Sustainability & 0.10 & 0.47 & -1.79 \\
\hline Philantropy & -1.66 & 0.03 & 1.06 \\
\hline CSR & -1.02 & 0.70 & -0.51 \\
\hline \multicolumn{4}{|c|}{$\begin{array}{l}\text { Italy }(N=19 ; \text { Stress }=0.25 ; R S Q=0.54)(A L S C A L \\
\quad \text { Level }=\text { ordinal untie })\end{array}$} \\
\hline Corporate Governance & 1.78 & -0.97 & -0.36 \\
\hline Safety & -2.02 & 0.11 & -0.01 \\
\hline Business Ethics & -0.24 & -1.06 & 0.97 \\
\hline Code of Ethics & 0.05 & -0.54 & 1.32 \\
\hline $\begin{array}{l}\text { Stakeholder } \\
\text { Management }\end{array}$ & -0.51 & 0.37 & -1.41 \\
\hline Shareholder Value & 0.9 & 0.32 & -1.19 \\
\hline Sustainability & -0.47 & -0.1 & -1.09 \\
\hline Philantropy & 0.63 & 2.46 & 0.7 \\
\hline CSR & -0.13 & -0.59 & 1.06 \\
\hline
\end{tabular}

Table 5 continued

\begin{tabular}{|c|c|c|c|}
\hline Element & $\begin{array}{l}\text { Dimension } \\
1\end{array}$ & $\begin{array}{l}\text { Dimension } \\
2\end{array}$ & $\begin{array}{l}\text { Dimension } \\
3\end{array}$ \\
\hline \multicolumn{4}{|c|}{$\begin{array}{l}\text { France }(N=19 ; \text { Stress }=0.21 ; R S Q=0.33)(A L S C A L \\
\text { Level }=\text { ordinal untie })\end{array}$} \\
\hline Corporate governance & 1.60 & 0.57 & -0.41 \\
\hline Safety & 0.71 & -0.91 & -1.38 \\
\hline Business ethics & 0.46 & -1.09 & 1.05 \\
\hline Code of Ethics & -0.50 & -1.60 & 0.44 \\
\hline $\begin{array}{l}\text { Stakehoder } \\
\text { management }\end{array}$ & 0.84 & 0.33 & 1.33 \\
\hline Shareholder value & 0.31 & 0.49 & -1.67 \\
\hline Sustainability & -0.66 & 1.25 & 0.75 \\
\hline Philanthropy & -2.08 & -0.38 & -0.38 \\
\hline CSR & -0.68 & 1.35 & 0.28 \\
\hline \multicolumn{4}{|c|}{$\begin{array}{l}\text { Spain }(N=20 ; \text { Stress }=0.17 ; R S Q=0.77)(A L S C A L \\
\text { Level }=\text { ordinal })\end{array}$} \\
\hline Corporate Governance & 0.73 & 1.30 & -0.69 \\
\hline Safety & 0.96 & 1.40 & 0.89 \\
\hline Business Ethics & -0.70 & -0.59 & 1.35 \\
\hline Code of Ethics & -0.50 & -0.40 & 1.45 \\
\hline $\begin{array}{l}\text { Stakeholder } \\
\text { Management }\end{array}$ & 0.05 & -0.47 & -1.24 \\
\hline Shareholder value & 1.89 & -0.96 & 0.53 \\
\hline Sustainability & -0.38 & -0.91 & -0.89 \\
\hline Philanthropy & -1.72 & 1.47 & -0.35 \\
\hline CSR & -0.35 & -0.85 & -1.04 \\
\hline
\end{tabular}

frequency in which constructs were mentioned. The construct category most frequently mentioned across all country samples was 'degree of compliance vs. voluntariness'. More than half of the interviewees mentioned this construct category. Furthermore, $40 \%$ of the small business owner-managers in the six countries mentioned the construct categories 'relevance for own situation', 'essentiality', 'ethical content', 'internal vs. external'. These construct categories reflect long standing debates in the CSR field including: should CSR be mandatory (law) or voluntary? Does CSR have an ethical foundation?, and is CSR essential to business or not? The fact that 'internal' (responsibility mainly towards employees) versus 'external' (responsibility towards external stakeholders) was fairly frequently mentioned by the respondents may indicate a distinct 'separation' of different responsibility categories in the mind of SME owner-managers. More than $25 \%$ of the respondents cited the construct categories related to a traditional dichotomy in CSR: 'economic' (profits, short term, company, strategic, opportunism) versus 'value' (values, long term, personal, conviction) such as 'values vs. profitability', 'long vs. short term', 'company-related vs. personal', 'strategic vs. operational' and 'opportunism vs. conviction'. The frequent mention of 


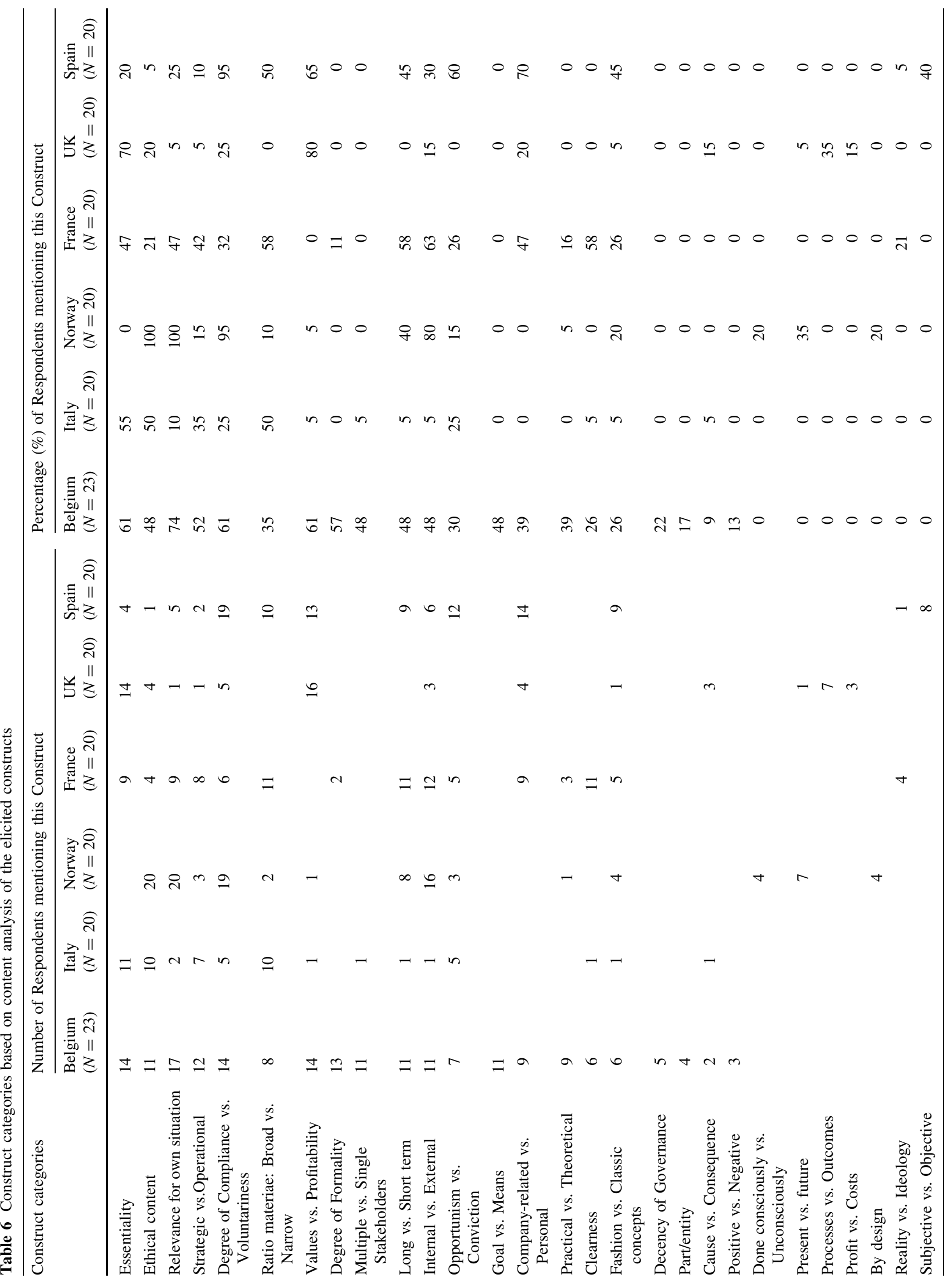




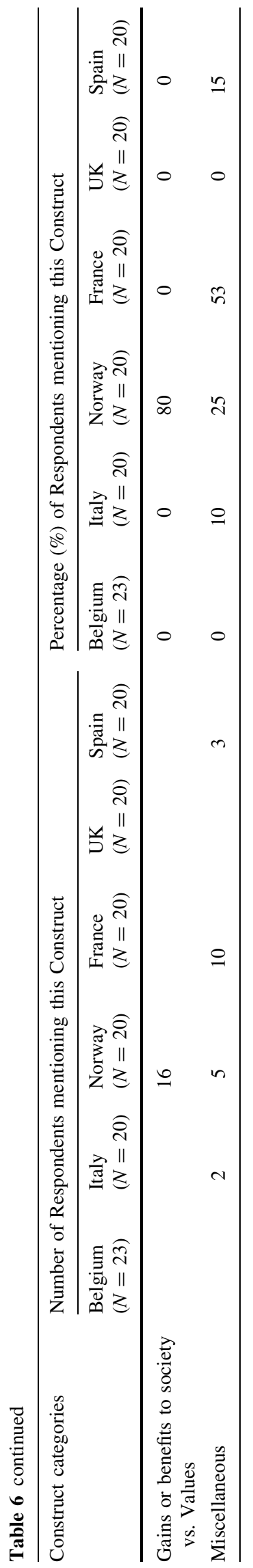

'company-related' vs. 'personal' may again be a reflection of SME owner-managers' life worlds, in which their personal responsibility is considered important alongside the responsibility of the organisations they run. Only $20 \%$ of the interviewees mentioned the construct category 'fashionable vs. classic concept'.

The other half of the 30 construct categories were found in only one, two or three countries. Some construct categories were mainly elicited in one specific country: 'done consciously vs. unconsciously', 'by design' and 'gains/ benefit for society vs. not' were only mentioned by Norwegian respondents; 'subjective vs. objective' only by Spanish respondents; 'reality vs. ideology' by French respondents; 'processes vs. outcomes' by British respondents; or 'cause vs. consequence', 'part vs. entity', 'positive vs. negative', by Belgian respondents. Some of these 'unique' constructs were only mentioned a few times in the sample and may, therefore, be either simply a variation of a theme (e.g. 'part vs. entity' a variation on 'encompassing vs. specific'). Other unique concepts were mentioned more frequently, and therefore merit interpretation. For example, 'gains/benefit for society vs. not' in the Norwegian sample may reflect the fact that in the Norwegian language 'social' can also mean 'societal'. The bipolar construct 'processes vs. outcomes', mentioned frequently in the UK sample, may indicate that UK SME owner-managers have a tendency to separate means from ends.

To sum up, looking at the constructs that make up the model alone, there is a remarkable similarity regarding the choice of constructs across all countries, despite a few differences.

Distances Between CSR and Other Related Concepts in the Mental Maps

\section{Country Common Spaces or Mental Maps}

We now take a step further and look at each country's mental map representing how CSR and the other eight concepts (business ethics, corporate governance, sustainability, stakeholder management, shareholder value, philanthropy, safety and code of ethics) relate to each other in the common space, which was drawn based on the ratings the respondents gave to each construct (see Fig. 1). Following this visual representation-with red lines connecting CSR, business ethics and corporate governance in each mental model for better visualisation-a different picture of cognition emerges.

The first 'visual' result is that none of the country mental maps is equal, so we can conclude that different mental models exists regarding CSR and other related concepts in the six countries. Also, if we compare the different mental maps by country, we find that for some countries (Norway, France, Italy) all concepts appear 
somewhat closer to each other, whereas in other countries (Spain, Belgium, United Kingdom) the concepts are further away from each other. We can thus argue that in some countries the concepts CSR, sustainability, stakeholder management, shareholder value are less differentiated in the minds of SME owner-managers than in others.

\section{Euclidean Distances}

We now consider the individual ED between individual CSR concepts within the country common spaces or mental maps (Table 7), and we notice both differences and similarities in the distances between CSR and the other concepts.

In the following paragraphs, we shall explore these commonalities and differences further for each concept. In interpreting these results, we refer to features of the national (macro) context: language, national traditions and organisation of the economic system including government policies and dissemination channels, thereby linking our findings regarding SME owner-managers' cognition to macro-level variables.

Table 7 shows that safety (ED between 2.28 and 3.24), shareholder value (ED between 2.35 and 3.2) and corporate governance (ED between 2.18 and 3.12) are regarded as being relatively distant from CSR in the SME ownermanagers' mental models across all six countries. Possible explanations for these results include that safety is interpreted by SME owner-managers as an issue of primarily legal compliance or protection of employees, whereas CSR is regarded a more voluntary concept relating to broader responsibilities. With regards to shareholder value SME owner-managers might view 'shareholder value' as something more relevant for stock-market listed companies or might be less concerned about the immediate financial return of CSR. In the UK, shareholder value was often considered an 'outcome', whereas CSR was related to how the company was run. With regards to corporate governance, according to the qualitative responses from our interviewees, the large distance may stem from a perception that corporate governance is a concept that is either more relevant to larger stock-market listed companies than to (often family-owned) SMEs, or a concept that refers to following certain rules and regulations regarding board composition, accounting and auditing only.

Philanthropy shows comparable ED for the six countries. Philanthropy is in all countries clearly set apart from CSR, although they are somewhat closer positioned in the UK $(E D=1.82)$. The categorisation of philanthropy as an important part of CSR' a view put forward by the dominant Anglo-Saxon literature (Carroll 1991), is thus not confirmed for European SME owner-managers. They do not appear to perceive philanthropy as a corporate theme, but instead regard it as a personal activity (as confirmed in our qualitative data). Especially in Spain and in Italy, philanthropy is seen as an SME managers' personal initiative rather than a business initiative. The Mediterranean approach to philanthropy is rooted in concepts related to Catholic Social Teaching: the concept of charity 'to help the under-privileged in your community' and the concept of 'the common good' which aims at making the community thrive. As a religious concept it is perceived as having a private dimension. Also, Norwegian ownermanagers do not seem to take philanthropy into consideration when setting a business agenda. There is no tradition for philanthropy in Norway and there are no tax incentives, as many Norwegian owner-managers pointed out. Philanthropy (not sponsorship in sport, culture and the arts) is foreign to Norwegians since the needs which philanthropy normally addresses are taken care of by the government and the social welfare system, which covers everyone, even if they do not work. The shortest distance, even though still a considerable one, was found in the UK. This is an indication that some British owner-managers may regard philanthropy as part of CSR, which in turn might be influenced by the Anglo-Saxon economic context in which they operate. In line with Matten and Moon's (2008) arguments, the fact that European corporations are less inclined to philanthropy than North American equivalents may reflect the assumption that the relatively high level of corporate taxation and more developed European welfare states should move the responsibility for philanthropic activities away from companies towards governments.

For the following concepts, we found a more varied picture regarding the ED.

As stated before, there is a debate in academic literature as to the extent to which CSR and business ethics are interchangeable terms (Joyner and Payne 2002); Fassin et al. 2011). Our data show mixed results: while CSR is perceived as being distant from business ethics in most European countries, and especially in France $(E D=2.80)$, CSR and business ethics are considered to be very close in Italy (0.49). One possible explanation of the proximity between these terms in Italy could lie in the country's cultural and political tradition. Certainly, the presence of the Vatican in the centre of the country has influenced its culture. The strong religious and social commitment in Italian culture is witnessed, and influenced, by the wellestablished and widespread presence of numerous religious and civil society organisations. In fact, the term 'social' has been widely used (even if, sometimes, with different meanings) by different political and religious actors (for example, in Catholic Social Thought). All these factors facilitate the interpretation of the terms 'social' as something linked with a 'moral or ethical duty' and the concept of 'ethics' as 'social justice'. This interpretation is also reflected in academic studies of business in Italy. Since its 
Table 7 Euclidean Distances between major concepts in the group spaces

\begin{tabular}{lllllll}
\hline ED between Concepts & Belgium & Italy & Norway & France & UK & Spain \\
\hline CSR-Business Ethics & 2.35 & 0.49 & 1.67 & 2.80 & 2.07 & 2.43 \\
CSR-Corporate Governance & 2.18 & 2.41 & 3.12 & 2.50 & 2.79 & 2.43 \\
CSR-Stakeholder Management & 1.66 & 2.68 & 2.62 & 2.11 & 1.57 & 0.59 \\
CSR-Sustainability & 0.49 & 2.23 & 1.26 & 0.48 & 1.72 & 0.16 \\
CSR-Philanthropy & 2.77 & 3.16 & 2.05 & 2.33 & 1.82 & 2.78 \\
CSR-Shareholder value & 2.87 & 2.64 & 3.20 & 2.35 & 2.79 & 2.74 \\
CSR-Code of Ethics & 2.57 & 0.32 & 1.73 & 2.97 & 2.18 & 2.53 \\
CSR-Safety & 2.78 & 2.28 & 2.69 & 3.13 & 3.12 & 3.24 \\
Corporate Governance-Business Ethics & 2.59 & 2.42 & 2.75 & 2.48 & 2.66 & 3.13 \\
Corporate Governance-Philanthropy & 3.89 & 3.76 & 3.30 & 3.80 & 3.42 & 2.48 \\
Corporate Governance-Stakeholder Management & 2.86 & 2.86 & 2.52 & 1.91 & 2.17 & 1.97 \\
Corporate Governance-Sustainability & 1.76 & 2.52 & 2.73 & 2.63 & 2.50 & 2.48 \\
Business Ethics—Philanthropy & 2.39 & 3.63 & 3.24 & 2.99 & 2.60 & 2.86 \\
Business Ethics-Stakeholder Management & 2.90 & 2.79 & 2.29 & 1.49 & 3.07 & 2.70 \\
Business Ethics-Sustainability & 2.33 & 2.28 & 0.93 & 2.60 & 2.04 & 2.29 \\
Business ethics-Code of Ethics & 0.44 & 0.69 & 0.19 & 1.24 & 1.08 & 0.30 \\
Stakeholder Management—Sustainability & 1.94 & 0.57 & 2.83 & 1.85 & 2.02 & 0.71 \\
\hline
\end{tabular}

inception in 1927, scholars of Italian Economia Aziendale (business administration) have implicitly drawn a close link between business administration, ethics and social responsibility. The azienda is, in fact, conceptualised as an economic institution that cannot be separated from its social, ethical and economic aspects: all these characteristics coexist in all decision-making (Signori and Rusconi 2009). Despite this long history, both terms CSR and business ethics have only recently proliferated and become more widespread in Italy. Business ethics has been translated in different ways (etica degli affari, etica d'impresa, etica aziendale, etc.) with slightly different connotations. However, Italian capitalism is based on small, often family, businesses where it is more common to talk about sociality or solidarity than to refer to business ethics or CSR. In effect, all the interviewees, even if they gave different interpretations of the term, appeared to link the concept of business ethics with a social dimension and thus closely associated it with CSR (responsabilità sociale d'impresa).

So, while in Italy being ethical equates to being socially responsible, other countries differentiate between doing business with integrity and being socially responsible. France, for example, showed the highest ED between CSR and business ethics ( $E D=2.80)$, and also between business ethics and code of ethics. In France, business ethics is regarded as a 'private' concept which one either has or does not have (ethics is closely associated with personal moral values) and which one does not talk about, like one does not talk about one's religion. Hence, the relatively high Euclidean distance between business ethics and code of ethics, which is regarded as formalised 'public' expression of company values. CSR is also regarded as a 'public' concept that can be talked about. Hence, disclosure about CSR is more acceptable. This may be explained by the fact that CSR is regarded as a fashionable term, a buzzword, or maybe because CSR has been overtly promoted by business associations and disseminated by the press.

After the Brundtland Report launched the notion of sustainable development in 1987, the term sustainability has received a lot of media attention, especially in relation to the issue of climate change. The academic literature notes an overlapping of the terms CSR and sustainability (Schwartz and Carroll 2008; Wheeler et al. 2003). Our data showed differences in ED between CSR and sustainability across the different countries. For example, the concepts were rather clearly set apart in Italy $(\mathrm{ED}=2.23)$, but seemed rather closely related in Belgium, France and Spain ( $\mathrm{ED}=0.49,0.48$ and 0.16 , respectively). This difference may be explained by the meaning of the term that sustainability may possess in different languages. Sustainability, in fact, is not a clear concept. Most SME managers related this concept to responsibility for 'green business', although some also referred to 'the long term view' of business. Sustainability thus possesses a double meaning: business sustainability and the green aspect of sustainable development. Even in English, sustainability has this double meaning, and this was reflected in the answers of the UK respondents. Translating the term into another language, either one or the other meaning may become more apparent. For example, in Italy owner-managers pointed out that 'sostenibilità' is a business concept, closely linked to a long-term vision, while CSR is more likely to cover different issues, including responsibility towards 
the environment. In France, the term développement durable was not linked to long-term business sustainability. In the Dutch speaking part of Belgium there was a close association between CSR and sustainability. This link may possibly be caused by the content and format of the terms in the Dutch language: CSR (maatschappelijk verantwoord ondernemen or MVO) and sustainability (duurzaam ondernemen) are used in Dutch in the verb-form 'ondernemen' (to enterprise), while corporate governance (deugdelijk bestuur) uses a noun 'bestuur' (governance). The verbforms of CSR and sustainability compared with the nounform of the other concepts may add to the perception that CSR and sustainability are perceived as synonyms, thus reinforcing the all-encompassing perception of CSR. In Norway, 'barekraftig utvikling' is also strongly associated with 'green issues', especially as the country is the home of the prime minister after whom the famous Brundtland report on sustainable development is named.

The term CSR was introduced and promoted in Europe in the late 1990s, and received a definitive impetus in 2001 following the publication of the EU 2001 Green Paper 'Corporate social responsibility-A business contribution to sustainable development' (Cantó-Milá and Lozano, 2009; Habisch et al., 2004). The use of both terms CSR and sustainable development in the title of this EU Green Paper may have contributed to some confusion. In particular, in Spain the implementation of CSR initiatives was strictly linked to the launch of the EU 2001 Green Paper. Hence in Spain both public bodies and business practitioners might be more likely to use these terms indiscriminately.

Stakeholder management is a term which has achieved much popularity in management circles (Schwartz and Carroll 2008), and is also found to be closely related to CSR (Garriga and Melé 2004; Wheeler et al. 2003). Large ED were found between stakeholder management and CSR in Italy $(E D=2.68)$, Norway $(E D=2.62)$ and France $(\mathrm{ED}=2.11)$ while in Belgium $(\mathrm{ED}=1.66)$ and the $\mathrm{UK}$ $(\mathrm{ED}=1.57)$ the concepts were positioned somewhat closer. Especially in Spain, stakeholder management was rather closely related to $\mathrm{CSR}(\mathrm{ED}=0.59)$. The small Euclidean Distance in Spain might be explained by the fact that the concept of CSR was introduced in Spain through the EU2001 Green Paper, in which the two terms CSR and stakeholder management appeared alongside each other. In Norway, by contrast, when the Confederation of Norwegian Enterprises in 2002 sought to adopt CSR as 'Bedriftens Samfunnsansvar' or Businesses' Responsibility in and for Society, they actually transformed the concept, linking it to Norwegian historical traditions, norms and values. When the Norwegian government issued a White Paper in 2009 it was called - 'Corporate Social Responsibility in a Global Economy'. The emphasis was on promoting 'global welfare-capitalism', interpreted by some more as a political agenda, rather than the business case for CSR. This could explain the distance separating it from the 'more managerial' concept of stakeholder management.

\section{Distance Triangles}

The literature in various management fields including strategy and decision-making, organisation and governance of corporations, as well as business and society, has identified CSR, business ethics and corporate governance as three major (and interrelated) concepts (Carroll 1999). These concepts also reflect the major debates that have emerged from different academic fields around management, values and governance (Fassin and Van Rossem 2009; Fassin et al. 2011). Based on the ED, Fig. 2 represents the triangles formed by the concepts CSR, business ethics (BE) and corporate governance $(\mathrm{CG})$ for the various countries.

In these triangles, the concepts sustainability (SU) and stakeholder management (ST) have been positioned in a geometric projection, and linked with dotted lines to CSR in order to visualise how respondents discern these three concepts. Looking at the form of the triangle CSR-BE-CG, we see a common equilateral pattern for France, Belgium and the UK; an isosceles triangle form for Norway and Spain; and a line form for Italy, where the distance between business ethics and CSR is extremely small.

These triangles visualise the fact that the results of our study do not completely follow Amable's (2003) categorisation of forms of capitalism. While our study confirms a number of differences between the countries in the four categories, we also find differences within the countries belonging to the same category of capitalism or national business systems. The three dimensions of the group space for the Mediterranean countries, Italy and Spain, do not coincide. Whereas the Euclidean distance triangles show a certain similarity between the three major concepts for France and Belgium, differences occur in relation to the stakeholder management concept.

\section{Discussion and Implications}

From our results, two broad findings emerge. The first one concerns the cognition of SME owner-managers with regard to CSR and related concepts. Our results have shown that SME owner-managers do have a clear mental model of concepts related to CSR. Even if the interviewees made individual interpretations, their mental models show that they were able to differentiate between the various CSR terms. Although it has been argued that many SME ownermanagers simply have no time to collect the large amounts of information that are available to them, interpret this information and find the necessary business solutions (Hunt 
Fig. 2 Visual representation of Euclidean Distances between major concepts in the group spaces $^{4}$
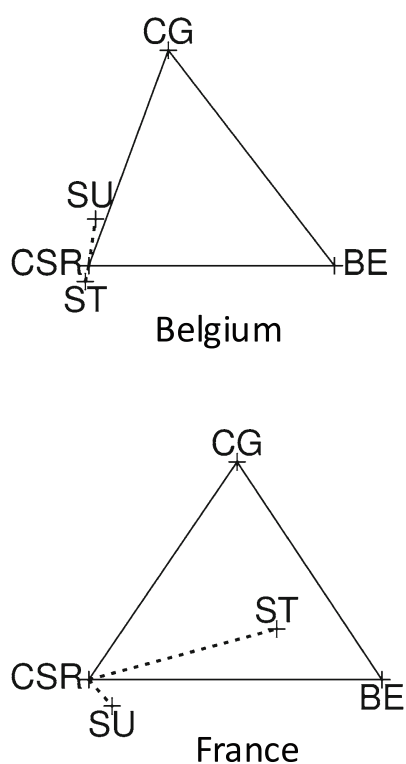

2000), we may conclude that the SME owner-managers interviewed engage in some kind of pragmatic sensemaking and that there is less confusion than might be feared on the basis of academic theory. Mitchell et al. (2007) argue that entrepreneurs use 'simplifying strategies' and a frequently mentioned characteristic of entrepreneurs is 'tolerance of ambiguity' (Begley 1995; Begley and Boyd 1987). Since the concepts related to CSR, as explained by academics, are rather ambiguous, the tolerance of ambiguity by entrepreneurs and SME owner-managers might explain why they are able to differentiate relatively well between the concepts, even with a limited knowledge of the theory. We also argue that the cognition of SME owner-managers is distinct to conceptualisations of terms found in the literature (Mitchell et al. 1997). For example, corporate governance, which in the academic literature is regarded as closely related to CSR in a corporate context (Aguilera et al. 2006; Money and Schepers 2007), was considered a concept that was distant from CSR by our respondents. Similarly, shareholder value had no close association with CSR in the mental models of SME owner-managers, despite the extensive discussion of the 'business case' in academic literature (Carroll and Shabana 2010). This is certainly a reflection of their organisational context; understandings of these concepts arise from the fact that their organisations are smaller in size, from the degree of resource constraints and from the fact that their ownership patterns are different to large corporations (Carland et al. 1984; Lepoutre and Heene 2006; Spence 1999). An interesting finding is the clear separation of CSR and business ethics in the mental models of our interviewed SME ownermanagers (with the exception of Italy). This is in contrast to common conceptualisations of CSR in studies that seek to measure the perception of the concept. In these studies, CSR

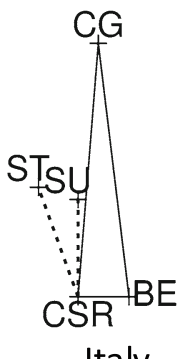

Italy

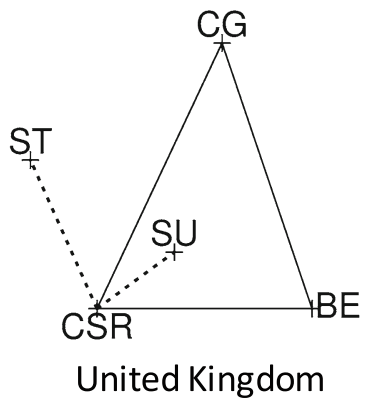

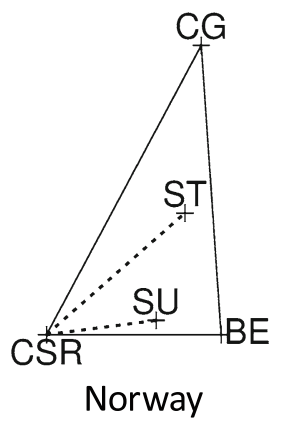

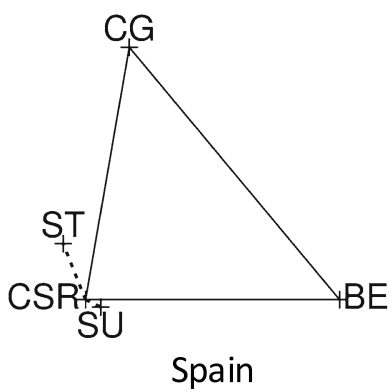

and business ethics are often intertwined, for example in Singhapakdi et al's (1996) PRESOR scale or in studies using Carroll's pyramid as a measure of CSR, in which ethics constitutes a part of CSR (e.g. Maignan 2001). It may be the case that SME owner-managers' personal values and ethics are spontaneously reflected in the running of their businessthus expressing their need for independence and autonomy (Spence 1999). CSR, by contrast, might be regarded by SME owner-managers as a wider concept that expresses societal expectations towards business in general.

Our second broad finding relates to Secchi's (2009) claim that individual managers' cognition in relation to CSR is dependent on external resources and socially shaped. In our analysis, we have particularly focused on the respondents' national context as one such external variable that influences cognition and we are able to confirm Secchi's (2009) claim. We have shown that language, the country's historical traditions and features of economic organisation (all of which are to some extent interlinked) are able to explain differences between the SME owner-managers' mental models with regards to CSR and related concepts across the six different countries-thus providing explicit evidence for the assumption that cognition is distributed.

For example, with regards to language, we found, that the term sustainability can take on different meanings when translated in different languages, which in turn, affects the position of the term in relation to CSR in SME ownermanagers' mental models. The influence of language also plays a clear role in Norway, where 'social' can also mean 'societal' (an understanding that is also embedded in the Scandinavian welfare tradition and contemporary governmental social policies, manifested by laws), thus creating a clear separation in the minds of owner-managers between 
broad responsibilities to society and more managerial concepts. This is shown, for example, in the large distance between CSR and stakeholder management in Norwegian SME owner-managers' mental models.

With regards to tradition, the findings for the Italian sample illustrate very well how a long-standing, wellembedded social and religious tradition (Catholic Social Thought) can shape understanding of business ethics and CSR. The long-standing welfare traditions in all countries in the sample are very likely to have influenced our respondents' mental 'distancing' of philanthropy from CSR: it is governments and not business organisations that are responsible for contributing to societal welfare, and if SME owner-managers want to contribute to the social good they often prefer to do it through personal giving rather than through their business (as reflected in the bipolar construct 'company-related' vs. 'personal').

Finally, a country's governmental policies seeking to promote CSR may also play a role, as shown in the case of Spain, where CSR, sustainability and stakeholder management are rather closely linked in the mind of SME owner-managers, due to a simultaneous dissemination of these terms based on the EU 2001 Green Paper.

It should be noted that reception, and perception, of CSR terms is evolutionary. Sometimes 'new' terms such as CSR, when introduced to practitioners via government policies, professional and trade bodies may be initially regarded as 'fashionable' or 'popular' (as seen by our respondents' use of the construct 'fashionable'). Even if these terms might be eventually accepted and adopted by practitioners, they might still retain particular meanings shaped by the respondents' particular contexts (Van Rossem and van Veen 2011).

Our study demonstrates that national environments are important and play a paramount role in SME ownermanagers' perception of CSR concepts. These findings have important implications for practice. Academics, policy makers, consultants and especially local promoters of CSR such as professional organisations who have adopted Anglo-Saxon management terminology must become aware that what they mean by a certain CSR concept is not always perceived in the same way in a non-Anglo-Saxon context, due to different national traditions and understandings of terms. Therefore, those seeking to promote responsible business practice should be more cautious in the use of CSR and concepts related to the term. In a complex and sensitive area such as CSR, supra-national government policy makers should ensure a common understanding of concepts before launching new initiatives. CSR scholars should help to formulate and disseminate clearer definitions of concepts, sensitive to local contexts (Freeman and Hasnaoui 2011; Matten and Moon 2004) as well as to the type of business organisation (Baden and Harwood 2013).

\section{Limitations and Further Research}

As the nature of our study was exploratory, and the first study of this kind, we acknowledge the following limitations regarding research design, method used and sampling technique.

Regarding research design, as we adopted RGT in our study as a specific cognitive approach, general criticisms levelled at cognitive theory and cognitive mapping techniques are also applicable to our research (Cossette and Audet 1992; Eden 1992; Eden and Ackermann 1998a). For example, Stubbart and Ramaprasad (1990, p. 262) noted 'it is not obvious or empirically proven that managers actually have cognitive maps in their heads or elsewhere'. If we take Weick's aphorism that 'we do not know what we think until we hear what we say' seriously then the process of articulation has a significant influence on present and future cognition (Eden 1992). In addition, interviews are social events, where the interviewer and interviewee interact, hence they reflect a social construction rather than the sole thoughts of the interviewee (Eden and Ackermann 1998b). At best, cognitive maps are artifacts of human reasoning (Huff 1990) and most techniques demand interpretive inputs from the researcher (Cossette and Audet 1992).

Further limitations arise because the data were collected by a different researcher in each country. Despite the use of the same interview format and training of the researchers by the project coordinators, each researcher has their own mental model and can be more sensitive to particular elicited constructs than to others. This, to some extent, affects the comparison of the content analysis. There are also some limitations with regards to the analysis of our grids, more specifically our decision to explore ED in the WMDS model. As we explained in the data analysis section, it was not possible to run a meaningful statistical robustness check on these distances. Our findings will, therefore, have to be treated as trends and tendencies that need further testing.

A final limitation relates to our decision to use convenience samples. Although the sample size used was sufficient for the purpose of eliciting constructs reflecting the universe of meaning surrounding a given situation (Ginsberg 1989), and our findings have enabled us to obtain new insights into our chosen research phenomenon, we have to be careful about drawing wider inferences, as was explained in the sampling section. Further research with more probabilistic sampling methods and more systematised multilevel analysis of how features of national contexts affect CSR cognition could be conducted, for which the findings of our exploratory study could be used. We propose that this should be done by formulating and testing of hypotheses using quantitative methods and larger and more stratified samples as more regular multilevel analyses do.

Finally, the timing of the interviews in the various countries was not simultaneous. However, since the major 
objective of our exploratory study is a relative comparison, the matter of timing should not have had a fundamental effect on the results of the research.

\section{Conclusion}

With this exploratory study, we have made a distinctive contribution to the emerging strand of CSR cognition research by comparing SME owner-managers' cognition related to CSR and related concepts across six different countries and by interpreting commonalities and differences using features of the respective national contexts (macro variables). Utilisation of RGT allowed for a rich data set and nuanced interpretation of the respondents' mental models, thereby transcending the constraints of methods used in previous CSR cognition research. Our main finding is that SME owner-managers' cognition is influenced by their national contexts. Our findings confirm the view that despite globalisation of economic activity, which is thought to foster uniformity, national differences continue to exist (Crouch and Streeck 1997; Den Hond et al. 2007, p. 218; Whitley 1999) with regard to cognition of CSR and related concepts. However, we also found that differences in cognition between countries do not neatly respond to clusters as proposed by comparative capitalism research (Midttun et al. 2006), but that the influence of language, cultural traditions and dissemination mechanisms leads to different mental models even within a country cluster (for example, Spain and Italy).

The findings from our study raise questions on the universality of cognition of academic concepts and on the universal adoption of Anglo-Saxon jargon. In other words, while management research, theory development and business school education have largely been dominated by the American model (Boyacigiller and Adler 1991), our study warns that US American management terminology should not be taken for granted, and that those seeking to promote responsible business practice need to be sensitive to the specificities of the national contexts in which they operate.

Acknowledgments We thank Denis Constales, Department of Mathematics at Ghent University for the drawing of Fig. 2

Open Access This article is distributed under the terms of the Creative Commons Attribution License which permits any use, distribution, and reproduction in any medium, provided the original author(s) and the source are credited.

\section{Appendix}

See Table 8

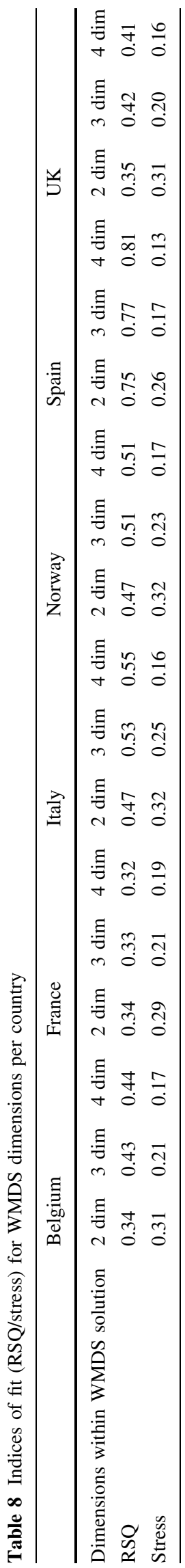




\section{References}

Abrahamson, E. (1996). Management fashion. Academy of Management Review, 21(1), 254-285.

Aguilera, R. V., Rupp, D. E., Williams, C. A., \& Ganapathi, J. (2007). Putting the $\mathrm{S}$ back in Corporate Social Responsibility: A multilevel theory of social change in organizations. Academy of Management Review, 32(3), 836-863.

Aguilera, R. V., Williams, C. A., Conley, J. M., \& Rupp, D. E. (2006). Corporate governance and social responsibility: A comparative analysis of the UK and the US. Corporate Governance: An International Review, 14(3), 147-158.

Aguinis, H., \& Glavas, A. (2012). What we know and don't know about Corporate Social Responsibility: A review and research agenda. Journal of Management, 18(4), 932-968.

Albareda, L., Lozano, J. M., Tencati, A., Midttun, A., \& Perrini, F. (2008). The changing role of governments in Corporate Social Responsibility: Drivers and responses. Business Ethics: A European Review, 17(4), 347-363.

Albareda, L., Lozano, J. M., \& Ysa, T. (2007). Public policies on Corporate Social Responsibility: The role of governments in Europe. Journal of Business Ethics, 74, 391-407.

Amable, B. (2003). The diversity of modern capitalism. Oxford: Oxford University Press.

Argandoña, A., \& von Weltzien Hoivik, H. (2009). Corporate Social Responsibility: One size does not fit all: Collecting evidence from Europe. Journal of Business Ethics, 89, 221-234.

Baden, D., \& Harwood, I. A. (2013). Terminology matters: A critical exploration of Corporate Social Responsibility terms. Journal of Business Ethics, 166, 615-627.

Bansal, P., \& Roth, K. (2000). Why companies go green: A model of ecological responsiveness. Academy of Management Journal, 43, 717-736.

Barnett, M. L., \& Salomon, R. M. (2012). Does it pay to be really good? Addressing the shape of the relationship between social and financial performance. Strategic Management Journal, 33(11), 1304-1320.

Basu, K., \& Palazzo, G. (2008). Corporate Social Responsibility: A process model of sensemaking. Academy of Management Journal, 33(1), 122-136.

Begley, T. M. (1995). Using founder status, age of firm, and company growth rate as the basis for distinguishing entrepreneurs from managers and smaller businesses. Journal of Business Venturing, 10(3), 249-263.

Begley, T. M., \& Boyd, D. P. (1987). Psychological characteristics associated with performance in entrepreneurial firms and smaller businesses. Journal of Business Venturing, 2(1), 79-93.

Bell, R. (2003). The repertory grid technique. In F. Fransella (Ed.), International handbook in personal construct psychology (pp. 95-103). Chichester: Wiley.

Boal, K. B., \& Peery, N. (1985). The cognitive structure of Corporate Social Responsibility. Journal of Management, 11(3), 71.

Bondy, K., Matten, D., \& Moon, J. (2008). Multinational corporation codes of conduct: Governance tools for Corporate Social Responsibility? Corporate Governance: An International Review, 16(4), 294-311.

Bood, R. P. (1998). Charting organizational learning: A comparison of multiple mapping techniques. In C. Eden \& J. C. Spender (Eds.), Managerial and organizational cognition: Theory, methods and research (pp. 201-230). London: Sage.

Boyacigiller, N., \& Adler, N. J. (1991). The parochial dinosaur: The organizational sciences in a global context. Academy of Management Review, 13(2), 262-291.

Campbell, J. L. (2007). Why would corporation behave in socially responsible ways? An institutional theory of Corporate Social
Responsibility. Academy of Management Review, 32(3), 946-967.

Cantó-Milá, N., \& Lozano, J. (2009). The Spanish discourse on Corporate Social Responsibility. Journal of Business Ethics, 87, 157-171.

Carland, J. W., Hoy, F., Boulton, W. R., \& Carland, J. A. C. (1984). Differentiating entrepreneurs from small business owners: A conceptualization. Academy of Management Review, 9(2), 354-359.

Caroll, J. D., \& Chang, J. J. (1970). Analyses of individual differences in multidimensional scaling via an $\mathrm{N}$-way general of EckartYoung decomposition. Psychometrika, 35, 283-919.

Carroll, A. B. (1991). The pyramid of Corporate Social Responsibility: Toward the moral management of organizational stakeholders. Business Horizons, 34(4), 39-48.

Carroll, A. B. (1999). Corporate Social Responsibility: Evolution of a definitional construct. Business and Society, 38, 268-295.

Carroll, A. B., \& Shabana, K. M. (2010). The business case for Corporate Social Responsibility: A review of concepts, research and practice. International Journal of Management Reviews, 12(1), 85-105.

Chiu, S., \& Sharfman, M. (2011). Legitimacy, visibility, and the antecedents of corporate social performance: An investigation of the instrumental perspective. Journal of Management, 37, $1558-1585$.

Cho, V., \& Wright, R. P. (2010). Exploring the evaluation framework of strategic information systems using repertory grid technique: A cognitive perspective from chief information officers. Behaviour \& Information Technology, 29(5), 447-457.

Cossette, P., \& Audet, M. (1992). Mapping of an idiosyncratic schema. Journal of Management Studies, 29(3), 325-347.

Cowley, S. J. (2007). The cognitive dynamics of distributed language. Language Sciences, 29, 575-583.

Cowley, S. J. (2009). Distributed language and dynamics. Pragmatics \& Cognition, 17(3), 495-507.

Cramer, J., van der Heijden, A., \& Jonker, J. (2006). Corporate Social Responsibility: Making sense through thinking and acting. Business Ethics: A European Review, 15(4), 380-389.

Crilly, D., Schneider, S. C., \& Zollo, M. (2008). Psychological antecedents to socially responsible behavior. European Management Review, 5(3), 175-190.

Crouch, C., \& Streeck, W. (1997). Political economy of modern capitalism. Mapping convergence \& diversity. London: Sage Publications.

Curran, J., \& Blackburn, R. (2001). Researching the small enterprise. London: Sage.

Daniels, K., \& Johnson, G. (2002). On trees and triviality traps: Locating the debate on the contribution of cognitive mapping to organizational research. Organization Studies, 23(1), 73-81.

Daniels, K., Johnson, G., \& de Chernatony, L. (1994). Differences in managerial cognitions of competition. British Journal of Management, 5(2), 21-29.

Daniels, K., Johnson, G., \& de Chernatony, L. (2002). Task and institutional influences on managers' mental models of competition. Organization Studies, 23(1), 31-62.

De George, R. T. (1987). The status of business ethics: Past and future. Journal of Business Ethics, 6(2), 201-212.

Den Hond, F., de Bakker, F., \& Neergaard, P. (2007). Managing Corporate Social Responsibility in action: Talking, doing, measuring. Aldershot: Ashgate.

Dunn, W. N., \& Ginsberg, A. (1986). A socio-cognitive network approach to organizational analysis. Human Relations, 39(11), 950-976.

Easterby-Smith, M. (1980). The design, analysis and interpretation of repertory grids. Journal of Man-Machine Studies, 13, 3-24. 
Eden, C. (1992). On the nature of cognitive maps. Journal of Management Studies, 29(3), 261-265.

Eden, C., \& Ackermann, F. (1998a). Analysing and comparing idiographic causal maps. In C. Eden \& J. C. Spender (Eds.), Managerial and organizational cognition: Theory, methods and research (pp. 192-209). London: Sage.

Eden, C., \& Ackermann, F. (1998b). Analysing and comparing idiographic causal maps. In J. Spender \& C. Eden (Eds.), Advances in personal construct psychology: New directions and perspectives (pp. 183-201). London: Sage.

Edwards, H. M., McDonald, V., \& Young, M. S. (2009). The repertory grid technique: Its place in empirical software engineering research. Information and Software Technology, 51, $785-798$.

Egels, N. (2005). Sorting out the mess, a review of definitions of ethical issues in business. Göteborg: Center for Business in Society, GRI, Göteborg University.

Epstein, E. (1987). The corporate social policy process: Beyond business ethics, Corporate Social Responsibility, and corporate social responsiveness. California Management Review, 29(3), 99-114.

European Commission (2014) What is an SME? http://ec.europa.eu/ enterprise/policies/sme/facts-figures-analysis/sme-definition/. Accessed 31 Jan 2014.

Fassin, Y., Van Rossem, A., \& Buelens, M. (2011). Small business Owner's Perceptions of CSR \& business ethics-related Concepts. Journal of Business Ethics, 98(3), 425-453.

Fassin, Y., \& Van Rossem, A. (2009). Corporate Governance in the CSR and Ethics Debate: Sensemaking of Experts and CEOs about Social Issues in Management. Corporate Governance: An International Review., 17(5), 573-593.

Fiol, M., \& Huff, S. (1992). Maps for managers: Where we are? Where do we go from here? Journal of Management Studies, 29(3), 267-285.

Fransella, F., Bell, R., \& Bannister, D. (2004). A manual for repertory grid technique. Chichester: Wiley.

Fransella, F., \& Neimeyer, R. (2003). George Alexander Kelly: The man and his theory. In F. Fransella (Ed.), International handbook in personal construct psychology (pp. 21-32). Chichester: Wiley.

Freeman, E. R., \& Hasnaoui, A. (2011). The meaning of Corporate Social Responsibility: The vision of four nations. Journal of Business Ethics, 3, 419-443.

Gallie, W. B. (1956). Art as an essentially contested concept. The Philosophical Quarterly, 6(23), 97-114.

Garriga, E., \& Melé, D. (2004). Corporate Social Responsibility theories: Mapping the theory. Journal of Business Ethics, 53(1/ 2), 51-71.

Ginsberg, A. (1989). Construing the business portfolio: A cognitive model for diversification. Journal of Management Studies, 26(4), $417-439$.

Godos-Díez, J., Fernández-Gago, R., \& Martínez-Campillo, A. (2011). How important are CEOs to CSR practices? An analysis of the mediating effect of the perceived role of ethics and social responsibility. Journal of Business Ethics, 98(4), 531-548.

Grice, J. W. (2002). Idiogrid: Software for the management and analysis of repertory grids. Behavior Research Methods, Instruments \& Computers, 34(3), 338-341.

Gully, S. M., Phillips, J. M., Castellano, W. G., Han, K., \& Kim, A. (2013). A mediated moderation model of recruiting socially and environmentally responsible job applicants. Personnel Psychology, 66(4), 935-973.

Habisch, A., Jonker, J., Wegner, M., \& Schmidpeter, R. (2004). Corporate Social Responsibility across Europe. Berlin: Springer.

Hagans, C. L., Neimeyer, G. J., \& Goodholm, J. C. R. (2000). The effect of elicitation methods on personal construct differentiation and valence. Journal of Constructivist Psychology, 13(2), $155-173$.

Hair, J., Anderson, R., Tatham, R., \& Black, W. (1998). Multivariate data analysis (Vol. 5). Upper Saddle River, NJ: Prentice Hall International.

Hodgkinson, G. P. (1997). Cognitive inertia in a turbulent market: The case of UK residential agents. Journal of Management Studies, 34(6), 921-945.

Hodgkinson, G. P. (2002). Comparing managers' mental models of competition: Why self-report measures of belief similarity won't do. Organization Studies, 23(1), 63-72.

Hodgkinson, G. P. (2005). Images of the competitive space. Houndmills, UK: Palgrave.

Hodgkinson, G. P., \& Wright, G. (2002). Confronting strategic inertia in a top management team: Learning from failure. Organization Studies, 23(6), 949-977.

Hox, J. (2002). Multilevel analyses: Techniques and applications. Mahwah, NJ: Erlbaum.

Huff, A. S. (1990). Mapping strategic thought. In A. S. Huff (Ed.), Mapping strategic thought (pp. 11-47). Chichester: Wiley.

Hunt, J. (2000). Environment, information and networks: How does information reach small and medium-sized enterprises. In R. Hillary (Ed.), Small and medium-sized enterprises and the environment (pp. 194-202). Sheffield, UK: Greenleaf.

Jackson, G., \& Deeg, R. (2006). Capitalist diversity and change: Recombinant governance and institutional entrepreneurs. British Journal of Industrial Relations, 44(3), 569-575.

Jamali, D., Zanhour, M., \& Keshishian, T. (2009). Peculiar strengths and relational attributes of SMEs in the context of CSR. Journal of Business Ethics, 87(3), 355-377.

Janckowicz, D. (2003). The easy guide to repertory grids. Chichester, UK: Wiley.

Jenkins, H. (2004). A critique of conventional CSR theory: An SME perspective. Journal of General Management, 29(4), 37-57.

Jones, N., Ross, H., Lynam, T., Perez, P., \& Leitch, A. (2011). Mental models: An interdisciplinary synthesis of theory and methods. Ecology and Society, 16(1), 1-12.

Joyner, B., \& Payne, D. (2002). Evolution and implementation: A study of values, business ethics and Corporate Social Responsibility. Journal of Business Ethics, 41, 297-311.

Kelly, G. (1955). Volume one: A theory of Personality. New York: Norton.

Lee, M. (2008). A review of the theories of Corporate Social Responsibility: Its evolutionary path and the road ahead. International Journal of Management Reviews, 10(1), 53-73.

Lepoutre, J., \& Heene, A. (2006). Investigating the impact of firm size on small business social responsibility: A critical review. Journal of Business Ethics, 67(3), 257-273.

Lim, D. K., Morse, E. A., Mitchell, R. K., \& Seawright, K. K. (2010). Institutional environment and entrepreneurial cognitions: A comparative business systems perspective. Entrepreneurship: Theory \& Practice, 34(3), 491-516.

Longenecker, J., Moore, C., \& Petty, W. (1996). Small business management, an entrepreneurial emphasis (Vol. 10). Cincinatti: South-Western College Publication.

Love, N. (2004). Cognition and the language myth. Language Sciences, 26(6), 252-544.

Luo, Y. (2006). Global dimensions of corporate governance. Malden: Blackwell Publishing.

Mackay, N. (1992). Identification, reflection, and correlation: Problems in the bases of repertory grid measures. International Journal of Personal Construct Psychology, 5(1), 57-75.

Maignan, I. (2001). Consumer perceptions of the Corporate Social Responsibility: A crosscultural comparison. Journal of Business Ethics, 30(1), 57-73. 
Maignan, I., Ferrell, O. C., \& Hult, G. T. M. (1999). Corporate citizenship: Cultural antecedents and business benefits. Journal of the Academy of Marketing Science, 27, 455-469.

Margolis, J., \& Walsh, J. P. (2003). Misery loves companies: Rethinking social initiatives by business. Administrative Science Quarterly, 48(2), 268-305.

Matten, D., \& Moon, J. (2004). Corporate Social Responsibility education in Europe. Journal of Business Ethics, 54(4), 323-337.

Matten, D., \& Moon, J. (2008). "Implicit" and "Explicit" CSR: A conceptual framework for a comparative understanding of Corporate Social Responsibility. Academy of Management Review, 93(2), 404-426.

Metzler, A. E., Gorden, H., \& Neimeyer, G. J. (2002). The effect of repertory grid scale size and rating direction on structural measures of differentiation. Journal of Constructivist Psychology, 15(2), 95-107.

Midttun, A., Gautesen, K., \& GjØlberg, M. (2006). The political economy of CSR in Western Europe. Corporate Governance: The International Journal of Effective Board Performance, 6(4), 369-385.

Mitchell, R., Agle, B., \& Wood, D. (1997). Toward a theory of stakeholder identification and salience: Defining the principle of who and what really counts. Academy of Management Review, 22(4), 853-886.

Mitchell, R., Busenitz, L. W., Bird, B., Caglio, C. M., McMullen, J. S., Morse, E. A., et al. (2007). The central question in entrepreneurial cognition research. Entrepreneurship, Theory and Practice, 31(1), 1-25.

Mitchell, R., Busenitz, L., Lant, T., McDougall, P., Morse, E., \& Brock Smith, J. (2002). Toward a theory of entrepreneurial cognition: Rethinking the people side of entrepreneurship research. Entrepreneurship Theory and Practice, 27(2), 93-104.

Money, K., \& Schepers, H. (2007). Are CSR and corporate governance converging?: A view from boardroom directors and company secretaries in FTSE100 companies in the UK. Journal of General Management, 33(2), 1-11.

Morgeson, F. P., Aguinis, H., Waldman, D. A., \& Siegel, D. S. (2013). Extending Corporate Social Responsibility research to the human resource management and organizational behavior domains: A look to the future. Personnel Psychology, 66(4), 805-824.

Neimeyer, G. (2002). Towards reflexive scrutiny in repertory grid methodology. Journal of Constructivist Psychology, 15(2), 89-95.

Orlitzky, M., Schmidt, F. L., \& Rynes, S. L. (2003). Corporate social and financial performance: A meta-analysis. Organization Studies, 24, 403-441.

Ormiston, M. E., \& Wong, E. M. (2013). License to Ill: The effects of Corporate Social Responsibility and CEO moral identity on Corporate Social Irresponsibility. Personnel Psychology, 66(4), 861-893.

Pater, A., \& van Lierop, L. (2006). Sense and sensitivity: The roles of organisation and stakeholders in managing Corporate Social Responsibility. Business Ethics: A European Review, 15(4), 339-351.

Pedersen, E. R. (2010). Modeling CSR: How managers understand the responsibilities of business towards society. Journal of Business Ethics, 91(2), 155-166.

Perrini, F. (2006). SMEs and CSR theory: Evidence and implications from an Italian perspective. Journal of Business Ethics, 67(2), 305-316.

Porter, M., \& Kramer, M. (2006a). Strategy \& society-The link between competitive advantage and Corporate Social Responsibility. Harvard Business Review, 84(12), 78-92.

Porter, M. E., \& Kramer, M. R. (2006b). Strategy \& society: The link between competitive advantage and Corporate Social Responsibility. Harvard Business Review, 84(12), 78-92.
Reeve, J., Owens, G. R., \& Neimeyer, G. J. (2002). Using examples in repertory grids: The influences on construct elicitation. Journal of Constructivist Psychology, 15(2), 121-126.

Reger, R. K. (1990). The repertory grid technique for eliciting the content and structure of cognitive constructive systems. In A. S. Huff (Ed.), Mapping strategic thought (pp. 301-309). Chichester: Wiley.

Reger, R. K., \& Palmer, T. B. (1996). Managerial categorization of competitors: Using old maps to navigate new environments. Organization Science, 7(1), 22-40.

Robertson, D. C., \& Nicholson, N. (1996). Expressions of Corporate Social Responsibility in UK firms. Journal of Business Ethics, 15(10), 1095-1106.

Rose, J. (2007). Corporate directors and social responsibility: Ethics versus shareholder value. Journal of Business Ethics, 73(3), 319-331.

Rupp, D. E., Shao, R., Thornton, M. A., \& Skarlicki, D. P. (2013). Applicants' and employees' reactions to Corporate Social Responsibility: The moderating effects of first-party justice perceptions and moral identity. Personnel Psychology, 66(4), 895-933.

Sacconi, L. (2006). A social contract account for CSR as an extended model of corporate governance (I): Rational bargaining and justification. Journal of Business Ethics, 68, 259-281.

Sapir, A. (2006). Globalization and the reform of European social models. Journal of Common Market Studies, 44(2), 369-390.

Schwartz, M. S., \& Carroll, A. B. (2008). Integrating and unifying competing frameworks. The search for a common core in the business and society field. Business and Society, 47(2), 148-186.

Secchi, D. (2007). Utilitarian, managerial and relational theories of Corporate Social Responsibility. International Journal of Management Reviews, 9(4), 347-373.

Secchi, D. (2009). The cognitive side of social responsibility. Journal of Business Ethics, 88(3), 565-581.

Sharma, S., \& Henriques, I. (2005). Stakeholder influences on sustainability practices in the Canadian forest products industry. Strategic Management Journal, 26, 159-180.

Signori, S., \& Rusconi, G. (2009). Ethical thinking in traditional Italian Economia Aziendale and the Stakeholder Management Theory: The search for possible interactions. Journal of Business Ethics, 89(3), 303-318.

Singhapakdi, A., Vitell, S. J., Rallapalli, K. C., \& Kraft, K. L. (1996). The perceived role of ethics and social responsibility: A scale development. Journal of Business Ethics, 15(11), 1131-1140.

Snijders, T. A. B., \& Bosker, R. J. (1999). Multilevel analysis: An introduction to basic and advanced multilevel modeling. London: Sage.

Spence, L. (1999). Does size matter? The state of the art in small business ethics. Business Ethics: A European Review, 8(3), 163-174.

Spence, L., \& Rutherfoord, R. (2001). Social responsibility, profit maximisation and the small firm owner-manager. Journal of Small Business and Enterprise Development, $8(2), 126-139$

Spurrett, D. (2004). Distributed cognition and integrational linguistics. Language Sciences, 26(5), 497-501.

Stewart, V., \& Stewart, A. (1981). Business applications of repertory grid (paperback ed.). London: McGraw-Hill Education.

Stewart, W. H, Jr, Watson, W. E., Carland, J. C., \& Carland, J. W. (1999). A proclivity for entrepreneurship: A comparison of entrepreneurs, small business owners, and corporate managers. Journal of Business Venturing, 14(2), 189-214.

Stubbart, C. I., \& Ramaprasad, A. (1990). Comments on empirical articles and recommendations for future research. In A. S. Huff (Ed.), Mapping strategic thought (pp. 251-288). Chichester: Wiley. 
Sturrock, K., \& Rocha, J. (2000). A multidimensional scaling stress evaluation table. Field Methods, 12, 49-60.

Sutton, J. (2004). Representation, levels, and context in integrational linguistics and distributed cognition. Language Sciences, 26(6), 503-524.

Takane, Y., Young, F. W., \& De Leeuw, J. (1977). Nonmetric individual differences multidimensional scaling: An alternating least-squares method with optimal scaling features. Psychometrika, 42, 7-67.

Tan, F., \& Hunter, G. (2002). The repertory grid technique: A method for the study of cognition in information systems. MIS Quarterly, 26(1), 39-57.

Thibault, P. J. (2011). First-order languaging dynamics and secondorder language: The distributed language view. Ecological Psychology, 23(3), 1-36.

Tolliver, R., \& Neimeyer, G. J. (2002). The effects of construct examples on the content and structure of personal construct system. Journal of Constructivist Psychology, 15(2), 127-138.

Trevino, L. K., \& Weaver, G. R. (2003). Managing ethics in business organizations. Stanford: Stanford University Press.

Van Rossem, A., \& van Veen, K. (2011). Managers' awareness of fashionable management concepts: An empirical study. European Management Journal, 29(3), 206-216.

Vogel, D. (1991). Business ethics: New perspectives on old problems. California Management Review, 33(4), 101-117.

Wheeler, D., Colbert, B., \& Freeman, E. R. (2003). Focusing on value: Reconciling Corporate Social Responsibility, sustainability and a stakeholder approach in a network world. Journal of General Management, 28(3), 1-23.
Whitley, R. (1999). Divergent capitalisms. The social structuring and change of business systems. Oxford: Oxford University Press.

Wijnen, K., Janssens, W., De Pelsmacker, P., \& Van Kenhove, P. (2002). Marktonderzoek met SPPS. Antwerpen-Apeldoorn: Garant.

Wood, D. J. (2010). Measuring corporate social performance: a review. International Journal of Management Reviews, 12(1), 50-84.

Wright, R. P. (2006). Rigor and relevance using repertory grid technique in strategy research. Research Methodology in Strategy and Management, 3, 289-341.

Wurthmann, K. (2013). A social cognitive perspective on the relationships between ethics education, moral attentiveness, and PRESOR. Journal of Business Ethics, 114(1), 131-151.

Yidong, T., \& Xinxin, L. (2013). How ethical leadership influence employees' innovative work behavior: A perpsective of intrinsic motivation. Journal of Business Ethics, 116(2), 441-455.

Zollo, M., Minoja, M., Casanova, L., Hockerts, K., Neergaard, P., Schneider, S., et al. (2009). Towards an internal change management perspective of CSR: EVIDENCE from project RESPONSE on the sources of cognitive alignment between managers and their stakeholders, and their implications for social performance. Corporate Governance: An International Review, $9(4), 355-372$. 